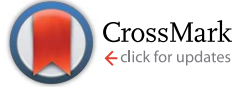

Cite this: Chem. Sci., 2015, 6, 1801

Received 25th September 2014 Accepted 13th December 2014

DOI: $10.1039 / c 4 s c 02970 d$

www.rsc.org/chemicalscience

\section{A faux hawk fullerene with PCBM-like properties $\uparrow$}

Long K. San, ${ }^{a}$ Eric V. Bukovsky, ${ }^{a}$ Bryon W. Larson, ${ }^{\text {ab }}{ }^{2}$ ames B. Whitaker, ${ }^{a}$ S. H. M. Deng, ${ }^{c}$ Nikos Kopidakis, ${ }^{\star b}$ Garry Rumbles, ${ }^{* b}$ Alexey A. Popov, ${ }^{* d}$ Yu-Sheng Chen, ${ }^{* e}$ Xue-Bin Wang, ${ }^{\star c}$ Olga V. Boltalina*a and Steven H. Strauss ${ }^{\star a}$

Reaction of $\mathrm{C}_{60}, \mathrm{C}_{6} \mathrm{~F}_{5} \mathrm{CF}_{2} \mathrm{l}$, and $\mathrm{SnH}(n-\mathrm{Bu})_{3}$ produced, among other unidentified fullerene derivatives, the two new compounds $1,9-\mathrm{C}_{60}\left(\mathrm{CF}_{2} \mathrm{C}_{6} \mathrm{~F}_{5}\right) \mathrm{H}$ (1) and 1,9- $\mathrm{C}_{60}\left(\right.$ cyclo- $\left.-\mathrm{CF}_{2}\left(2-\mathrm{C}_{6} \mathrm{~F}_{4}\right)\right)$ (2). The highest isolated yield of 1 was $35 \%$ based on $\mathrm{C}_{60}$. Depending on the reaction conditions, the relative amounts of 1 and 2 generated in situ were as high as $85 \%$ and $71 \%$, respectively, based on HPLC peak integration and summing over all fullerene species present other than unreacted $\mathrm{C}_{60}$. Compound 1 is thermally stable in 1,2 -dichlorobenzene (oDCB) at $160{ }^{\circ} \mathrm{C}$ but was rapidly converted to 2 upon addition of $\mathrm{Sn}_{2}(n-\mathrm{Bu})_{6}$ at this temperature. In contrast, complete conversion of 1 to 2 occurred within minutes, or hours, at $25^{\circ} \mathrm{C}$ in $90 / 10$ ( $/ / v)$ PhCN/ $\mathrm{C}_{6} \mathrm{D}_{6}$ by addition of stoichiometric, or sub-stoichiometric, amounts of proton sponge (PS) or cobaltocene $\left(\mathrm{CoCp}_{2}\right)$. DFT calculations indicate that when 1 is deprotonated, the anion $\mathrm{C}_{60}\left(\mathrm{CF}_{2} \mathrm{C}_{6} \mathrm{~F}_{5}\right)^{-}$can undergo facile intramolecular $\mathrm{S}_{N} \mathrm{Ar}$ annulation to form 2 with concomitant loss of $\mathrm{F}^{-}$. To our knowledge this is the first observation of a fullerene-cage carbanion acting as an $S_{N} A r$ nucleophile towards an aromatic $\mathrm{C}-\mathrm{F}$ bond. The gas-phase electron affinity (EA) of 2 was determined to be $2.805(10) \mathrm{eV}$ by low-temperature PES, higher by $0.12(1) \mathrm{eV}$ than the EA of $\mathrm{C}_{60}$ and higher by $0.18(1)$ $\mathrm{eV}$ than the EA of phenyl- $\mathrm{C}_{61}$-butyric acid methyl ester (PCBM). In contrast, the relative $E_{1 / 2}(0 /-)$ values of 2 and $C_{60},-0.01(1)$ and $0.00(1) \mathrm{V}$, respectively, are virtually the same (on this scale, and under the same conditions, the $E_{1 / 2}(0 /-)$ of PCBM is $\left.-0.09 \mathrm{~V}\right)$. Time-resolved microwave conductivity chargecarrier yield $\times$ mobility values for organic photovoltaic active-layer-type blends of 2 and poly-3hexylthiophene (P3HT) were comparable to those for equimolar blends of PCBM and P3HT. The structure of solvent-free crystals of 2 was determined by single-crystal X-ray diffraction. The number of nearest-neighbor fullerene-fullerene interactions with centroid $\cdots$ centroid $(\odot \cdots \odot)$ distances of $\leq 10.34 \AA$ is significantly greater, and the average $\odot \cdots \odot$ distance is shorter, for 2 (10 nearest neighbors; ave. $\odot \cdots \odot$ distance $=10.09 \AA$ ) than for solvent-free crystals of PCBM (7 nearest neighbors; ave. $\odot \cdots \odot$ distance $=$ 10.17 Å). Finally, the thermal stability of 2 was found to be far greater than that of PCBM.

\section{Introduction}

$\mathrm{We}^{1}$ and others ${ }^{2}$ have been investigating homoleptic perfluoroalkylfullerenes (PFAFs, fullerene $\left(\mathrm{R}_{\mathrm{F}}\right)_{n}$ ) such as 1,7$\mathrm{C}_{60}\left(\mathrm{R}_{\mathrm{F}}\right)_{2}\left(\mathrm{R}_{\mathrm{F}}=\mathrm{CF}_{3}, \mathrm{C}_{2} \mathrm{~F}_{5}, n-\mathrm{C}_{3} \mathrm{~F}_{7}, i-\mathrm{C}_{3} \mathrm{~F}_{7}, n-\mathrm{C}_{4} \mathrm{~F}_{9}, 2-\mathrm{C}_{4} \mathrm{~F}_{9}\right.$, and $\left.n-\mathrm{C}_{8} \mathrm{~F}_{17}\right),{ }^{3,4} \mathrm{C}_{74}\left(\mathrm{CF}_{3}\right)_{12},{ }^{5} \mathrm{C}_{84}\left(\mathrm{CF}_{3}\right)_{12},{ }^{2,6,7} 7,24-\mathrm{C}_{70}\left(\mathrm{C}_{2} \mathrm{~F}_{5}\right)_{2},{ }^{8}$ and

\footnotetext{
${ }^{a}$ Department of Chemistry, Colorado State University, Fort Collins, CO 80523, USA. E-mail: olga.boltalina@colostate.edu; steven.strauss@colostate.edu

${ }^{b}$ National Renewable Energy Laboratory, Golden, CO 80401, USA. E-mail: nikos. kopidakis@nrel.gov; garry.rumbles@nrel.gov

${ }^{c}$ Physical Sciences Division, Pacific Northwest National Laboratory, MS K8-88, P.O. Box 999, Richland, WA 99352, USA. E-mail: xuebin.wang@pnnl.gov

${ }^{d}$ Leibniz Institute for Solid State and Materials Research, 01069 Dresden, Germany. E-mail: a.popov@ifw-dresden.de

${ }^{e}$ ChemMatCARS Beamline, University of Chicago Advanced Photon Source, Argonne, IL 60439, USA. E-mail: yschen@cars.uchicago.edu

$\dagger$ Electronic supplementary information (ESI) available: Additional figures and tables described in the text. CSD-428507. For ESI and crystallographic data in CIF or other electronic format see DOI: $10.1039 / \mathrm{c} 4 \mathrm{sc0} 2970 \mathrm{~d}$
}

$C_{3}-\mathrm{C}_{60}\left(i-\mathrm{C}_{3} \mathrm{~F}_{7}\right)_{6}$ (ref. 9) since 2003. This very large class of fullerene $(\mathrm{X})_{n}$ derivatives has fostered an understanding of the relationships between fullerene addition patterns, LUMO shapes and relative energies, perfluoroalkyl chain lengths, and electrochemical/electron affinity properties ${ }^{\mathbf{4 1 0 , 1 1}}$ and has afforded a range of structurally similar PFAFs with $E_{1 / 2}(0 /-)$ values that vary by as much as $0.5 \mathrm{~V}$ to be used for fundamental organic photovoltaic (OPV) active-layer studies. ${ }^{12} \mathrm{We}$ have recently turned our attention to (i) fullerenes with perfluoroaryl derivatives (e.g., perfluorobenzyl) ${ }^{\mathbf{1 3}}$ and (ii) hydroPFAFs with one or more $\mathrm{H}$ atom substituents, ${ }^{\mathbf{1 4 , 1 5}}$ the latter so that their deprotonation and subsequent treatment with electrophiles $\mathrm{E}^{+}$would result in a variety of fullerene $(\mathrm{E})\left(\mathrm{R}_{\mathrm{F}}\right)_{n-1}$ derivatives for fundamental and applied studies.

We herein report the synthesis of $1,9-\mathrm{C}_{60}\left(\mathrm{CF}_{2} \mathrm{C}_{6} \mathrm{~F}_{5}\right) \mathrm{H}(\mathbf{1})$, shown in Fig. 1, and its unexpected transformation upon deprotonation or one-electron reduction to the exocyclic "fullerene with a faux hawk" product $1,9-\mathrm{C}_{60}\left(\right.$ cyclo- $\mathrm{CF}_{2}(2-$ $\mathrm{C}_{6} \mathrm{~F}_{4}$ )) (2), also shown in Fig. 1 (see also Fig. S-1; ESI figures 


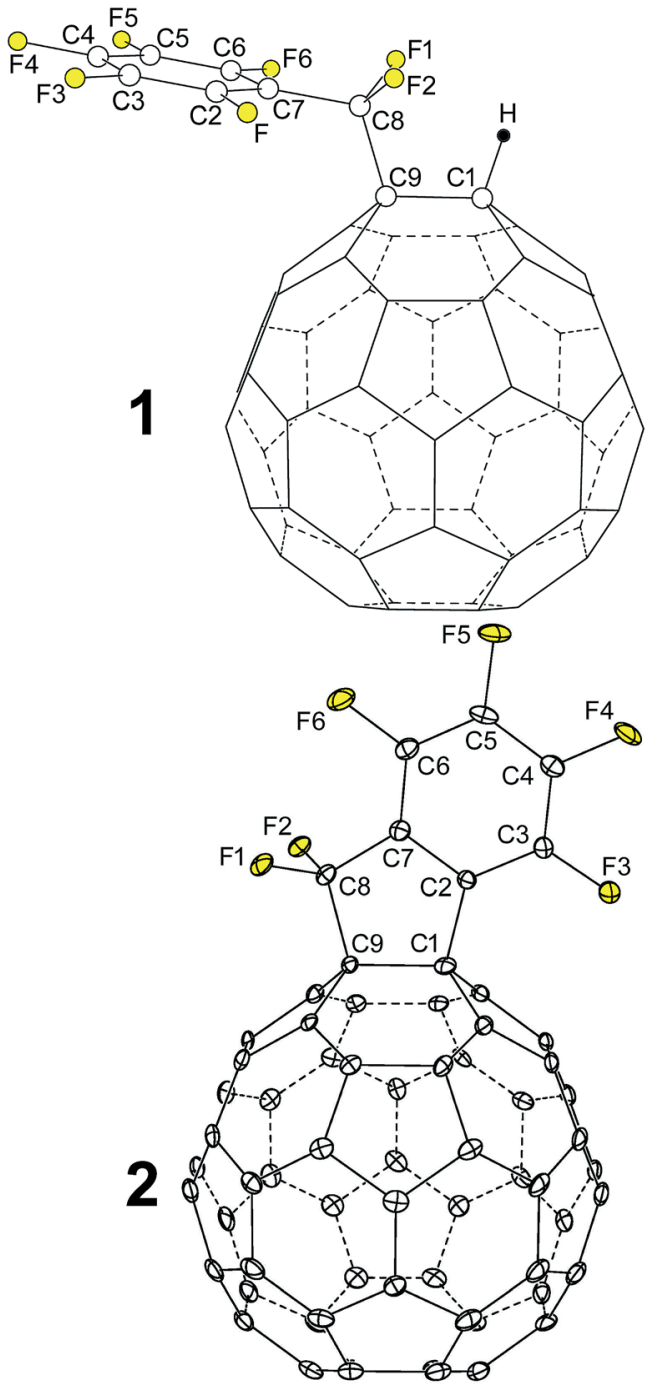

Fig. 1 OLYP DFT-optimized structure of $1,9-\mathrm{C}_{60}\left(\mathrm{CF}_{2} \mathrm{C}_{6} \mathrm{~F}_{5}\right) \mathrm{H}(1)$ and the $\mathrm{X}$-ray structure of $1,9-\mathrm{C}_{60}\left(\mathrm{CyClo}_{0}-\mathrm{CF}_{2}\left(2-\mathrm{C}_{6} \mathrm{~F}_{4}\right)\right)(2 ; 50 \%$ probability ellipsoids). Only the major twin portion of the $X$-ray structure is shown. The shape of compound 2 is reminiscent of a hairstyle known as the faux hawk, as shown in Fig. S-1.†

and tables, available in the ESI, $\uparrow$ are numbered T-1, T-2, S-1, S2 , etc.). We propose a reaction sequence for the transformation $\mathbf{1} \rightarrow \mathbf{2}+\mathrm{HF}$ that is supported by DFT calculations. The gas-phase electron affinities, solution reduction potentials, thermal stabilities, X-ray diffraction molecular structures, and solid-state packing in solvent-free crystals of 2, PCBM (phenyl- $\mathrm{C}_{61}$-butyric acid methyl ester), and $\mathrm{C}_{60}$ are compared and contrasted. Finally, we show that OPV activelayer thin films made from blends of 2 with poly-3-hexylthiophene (Р3HT), when studied using time-resolved microwave photoconductivity, exhibit photoinduced charge-carrier yield $\times$ mobility figures of merit that rival the OPV active-layer standard blend of PCBM with P3HT, which demonstrates the potential of 2 as an electron acceptor in OPV and other optoelectronic devices.

\section{Results and discussion}

\subsection{Synthesis of $1,9-\mathrm{C}_{60}\left(\mathrm{CF}_{2} \mathrm{C}_{6} \mathrm{~F}_{5}\right) \mathrm{H}(1)$ and $1,9-\mathrm{C}_{60}($ cyclo- $\left.\mathrm{CF}_{2}\left(2-\mathrm{C}_{6} \mathrm{~F}_{4}\right)\right)(2)$}

In 1996 Yoshida, Suzuki, and Iyoda reported that the reaction of $\mathrm{C}_{60}$, perfluoroalkyliodides $\left(\mathrm{R}_{\mathrm{F}} \mathrm{I}\right), \mathrm{SnH}(n-\mathrm{Bu})_{3}$, and a catalytic amount of the radical initiator AIBN in refluxing benzene for 30 $h$ produced $1,9-C_{60}\left(R_{F}\right) H$ derivatives in moderate yields depending on the ratio of the reagents. ${ }^{16}$ For example, with 12 equiv. $n-\mathrm{C}_{6} \mathrm{~F}_{13} \mathrm{I}, 5$ equiv. $\mathrm{SnH}(n-\mathrm{Bu})_{3}$, and 0.1 equiv. AIBN (based on $\left.\mathrm{C}_{60}\right)$, the yield of $1,9-\mathrm{C}_{60}\left(n-\mathrm{C}_{6} \mathrm{~F}_{13}\right) \mathrm{H}$ was $31 \%$ and $64 \%$ of the original $\mathrm{C}_{60}$ was recovered. With 12 equiv. $n-\mathrm{C}_{12} \mathrm{~F}_{25} \mathrm{I}, 14$ equiv. $\mathrm{SnH}(n-\mathrm{Bu})_{3}$, and 0.1 equiv. AIBN, the yield of $1,9-\mathrm{C}_{60}\left(n-\mathrm{C}_{12} \mathrm{~F}_{25}\right) \mathrm{H}$ was $26 \%$ and $67 \%$ of the original $\mathrm{C}_{60}$ was recovered. However, no fullerene products containing $\mathrm{R}_{\mathrm{F}}$ groups were obtained in the absence of AIBN. ${ }^{16}$

In our hands, no AIBN was necessary to prepare 1 when the solvent was 1,2- $\mathrm{C}_{6} \mathrm{H}_{4} \mathrm{Cl}_{2}$ (oDCB) and the temperature was $160{ }^{\circ} \mathrm{C}$. Furthermore, reaction times of only 1 or $2 \mathrm{~h}$ were sufficient to form appreciable amounts of $\mathbf{1}$, as shown in Fig. 2 and Table 1. This is probably due to the higher temperature for the reaction and a lower $\mathrm{C}-\mathrm{I}$ bond energy for $\mathrm{C}_{6} \mathrm{~F}_{5} \mathrm{CF}_{2} \mathrm{I}$ than for $n-\mathrm{C}_{6} \mathrm{~F}_{13} \mathrm{I}$ or $n-\mathrm{C}_{12} \mathrm{~F}_{25} \mathrm{I}$, both of which will result in more $\mathrm{C}_{6} \mathrm{~F}_{5} \mathrm{CF}_{2}{ }^{*}$ radicals present than the number of $\mathrm{R}_{\mathrm{F}}{ }^{\circ}$ radicals in the reactions of Yoshida et al. The mol\% values in Table 1 are based on HPLC peak relative integrations and are only approximate. They are listed so that trends in product ratios at various reaction temperatures, reaction times, and reagent mole ratios can be easily understood.

We propose that the formation of 1 from $\mathrm{C}_{6} \mathrm{~F}_{5} \mathrm{CF}_{2} \mathrm{I}$ and $\mathrm{SnH}(n-\mathrm{Bu})_{3}$ in oDCB at elevated temperatures is best

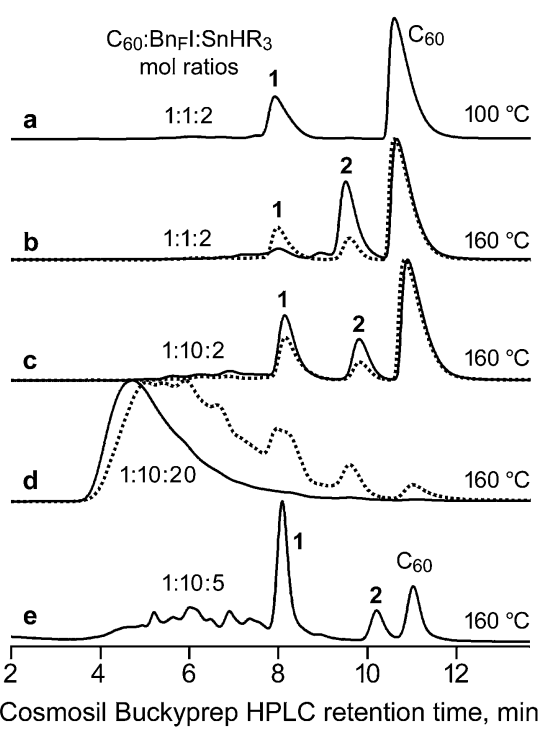

Fig. $2 \mathrm{HPLC}$ traces of $\mathrm{C}_{60}+\mathrm{C}_{6} \mathrm{~F}_{5} \mathrm{CF}_{2} \mathrm{I}+\mathrm{SnH}(n-\mathrm{Bu})_{3}$ reaction mixtures $\left(\mathrm{Bn}_{\mathrm{F}} \mathrm{I}=\mathrm{C}_{6} \mathrm{~F}_{5} \mathrm{CF}_{2} \mathrm{l} ; \mathrm{R}=n-\mathrm{Bu}\right)$. The dotted-line traces are for $1 \mathrm{~h}$ reactions; the solid-line traces are for $2 \mathrm{~h}$ reactions. See Table 1 for additional details. Compounds 1 and 2 are 1,9- $\mathrm{C}_{60}\left(\mathrm{CF}_{2} \mathrm{C}_{6} \mathrm{~F}_{5}\right) \mathrm{H}$ and 1,9$\mathrm{C}_{60}\left(\mathrm{cyclo}-\mathrm{CF}_{2}\left(2-\mathrm{C}_{6} \mathrm{~F}_{4}\right)\right)$, respectively. 
Table 1 Reactions producing 1,9- $\mathrm{C}_{60}\left(\mathrm{CF}_{2} \mathrm{C}_{6} \mathrm{~F}_{5}\right) \mathrm{H}(1)$ and 1,9- $\mathrm{C}_{60}\left(\right.$ cyclo $\left.-\mathrm{CF}_{2}\left(2-\mathrm{C}_{6} \mathrm{~F}_{4}\right)\right)(2)^{a}$

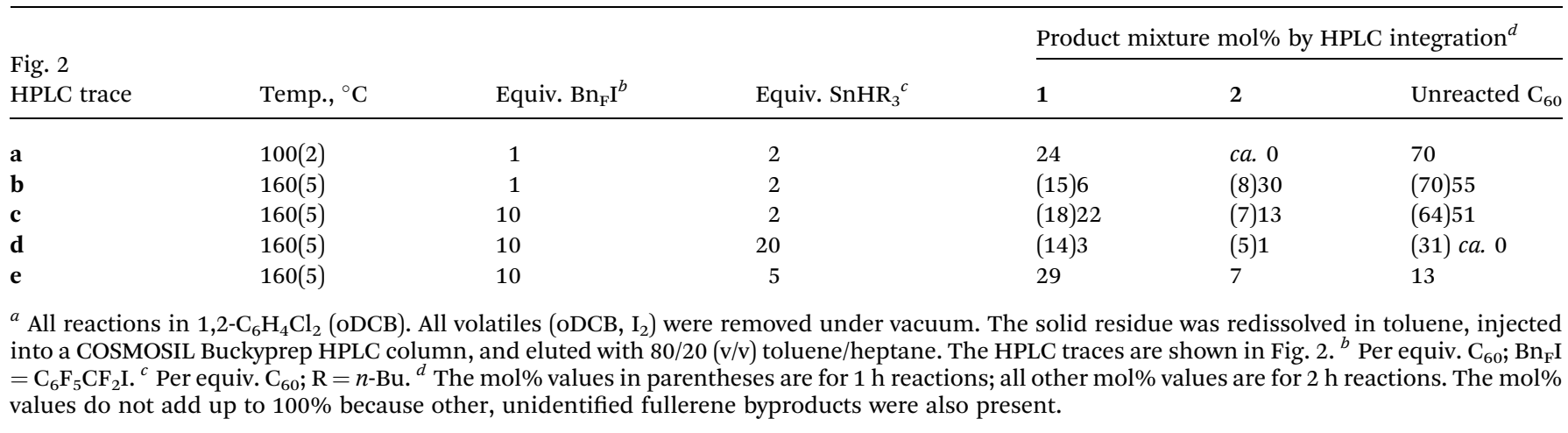

represented by the following balanced equation $\left(\mathrm{Bn}_{\mathrm{F}} \mathrm{I}=\right.$ $\left.\mathrm{C}_{6} \mathrm{~F}_{5} \mathrm{CF}_{2} \mathrm{I} ; \mathrm{R}=n-\mathrm{Bu}\right)$ :

$$
\begin{aligned}
\mathrm{C}_{60}+\mathrm{Bn}_{\mathrm{F}} \mathrm{I}+\mathrm{SnHR}_{3} \rightarrow & 1,9-\mathrm{C}_{60}\left(\mathrm{CF}_{2} \mathrm{C}_{6} \mathrm{~F}_{5}\right) \mathrm{H}(\mathbf{1})+1 / 2 \mathrm{I}_{2} \\
& +1 / 2 \mathrm{Sn}_{2} \mathrm{R}_{6}
\end{aligned}
$$

At $100{ }^{\circ} \mathrm{C}$ and $\mathrm{C}_{60}: \mathrm{R}_{\mathrm{F}} \mathrm{I}: \mathrm{SnHR}_{3}$ reagent mole ratios of $1: 1: 2$ (HPLC trace a in Fig. 2), compound 1 and $\mathrm{C}_{60}$ were virtually the only fullerene species present in the reaction mixture after $2 \mathrm{~h}$. The same amount of unreacted $\mathrm{C}_{60}$ was also present with the same reagent ratios when the temperature was $160{ }^{\circ} \mathrm{C}$ for $1 \mathrm{~h}$ (HPLC trace $\mathrm{b}$, dotted line), but in this case both 1 and 2 were present (in a ca. $2: 1 \mathrm{~mol}$ ratio). After $2 \mathrm{~h}$ (trace b, solid line), significantly less $\mathbf{1}$ and significantly more 2 were present (now in a ca. $1: 5 \mathrm{~mol}$ ratio). The HPLC traces labeled c and $d$ show the results of changing the reagent mole ratios for 1 $\mathrm{h}$ (dotted lines) and $2 \mathrm{~h}$ (solid lines) reactions. HPLC traces $\mathrm{d}$ indicate that a large excess of $\mathrm{SnHR}_{3}$ produces many other fullerene derivatives (presumably various hydrofullerenes) and much less 1 and 2 than when less $\mathrm{SnHR}_{3}$ was used. We conclude that $\mathbf{1}$ is an intermediate in the formation of 2 under the reaction conditions. It is possible that $\mathrm{SnR}_{3}{ }^{\cdot}$ radicals are involved, as shown in the following speculative balanced equation, but $\mathrm{SnFR}_{3}$ has not been positively identified:

$$
\begin{gathered}
1,9-\mathrm{C}_{60}\left(\mathrm{CF}_{2} \mathrm{C}_{6} \mathrm{~F}_{5}\right) \mathrm{H}(\mathbf{1})+2 \mathrm{SnR}_{3} \cdot \rightarrow 1,9-\mathrm{C}_{60}\left(\text { cyclo- }-\mathrm{CF}_{2}\left(2-\mathrm{C}_{6} \mathrm{~F}_{4}\right)\right) \\
(\mathbf{2})+\mathrm{SnHR}_{3}+\mathrm{SnFR}_{3}
\end{gathered}
$$

HPLC trace e in Fig. 2 represents a compromise set of reaction conditions that produced significant amounts of $\mathbf{1}$ and 2, relatively less unreacted $\mathrm{C}_{60}$, and relatively small amounts of the other fullerene byproducts. This reaction resulted in a 35\% isolated yield of $\mathbf{1}$ and a 7\% isolated yield of 2 after HPLC purification (both yields based on $\mathrm{C}_{60}$ ).

An alternate synthesis of 2 is the reaction of 1 with excess Proton Sponge (PS, 1,8-bis(dimethylamino)naphthalene) in $\mathrm{CH}_{2} \mathrm{Cl}_{2}$ at $23(1){ }^{\circ} \mathrm{C}$ for $24 \mathrm{~h}$. This reaction, which resulted in a $76 \%$ isolated yield of 2 based on $\mathbf{1}$, will be discussed in detail in Section 2.3. We also explored photochemical syntheses, but these invariably showed lower yields of $\mathbf{1}$ and $\mathbf{2}$ and will not be discussed further.

\subsection{Characterization of 1 and 2}

The negative-ion (NI) APCI mass spectrum of $\mathbf{1}$ exhibited an $\mathrm{m} / \mathrm{z}$ species at 937, which is consistent with $\mathrm{C}_{60}\left(\mathrm{CF}_{2} \mathrm{C}_{6} \mathrm{~F}_{5}\right)^{-}$, or $[\mathbf{1}-\mathrm{H}]^{-}$. The UV-vis spectrum of 1 (Fig. S-2†) exhibited absorption maxima at 324, 431, and $698 \mathrm{~nm}$. The $431 \mathrm{~nm}$ band in particular is characteristic of $1,9-\mathrm{C}_{60} \mathrm{X}_{2}$ or $1,9-\mathrm{C}_{60} \mathrm{XY}$ derivatives. ${ }^{17}$ In contrast, $\mathrm{C}_{60} \mathrm{XY}$ derivatives with the substituents on the para positions on a $\mathrm{C}_{60}$ hexagon (i.e., 1,7- $\mathrm{C}_{60} \mathrm{XY}$ ) generally exhibit a prominent band at $450 \mathrm{~nm}$. ${ }^{4}$ The singlet at $\delta 7.2$ in the ${ }^{1} \mathrm{H}$ NMR spectrum of 1 in $\mathrm{CDCl}_{3}$ is characteristic of a $\mathrm{C}_{60}-\mathrm{H}$ species $^{18-20}$ ( $c f . \delta 6.65$ for $\left.1,9-\mathrm{C}_{60}\left(\mathrm{CH}_{2} \mathrm{C}_{6} \mathrm{H}_{5}\right) \mathrm{H}^{20}\right)$.

The NI-APCI mass spectrum of 2 exhibited an $\mathrm{m} / \mathrm{z}$ species at 918, which is consistent with the formula $\mathrm{C}_{60}\left(\mathrm{CF}_{2} \mathrm{C}_{6} \mathrm{~F}_{4}\right)^{-}$. The UV-vis spectrum of 2 (Fig. S- $2 \dagger$ ) exhibited bands at 331, 430, and $687 \mathrm{~nm}$, which supports a 1,9-addition pattern for this compound as well (verified by X-ray crystallography). No resonance was observed in a ${ }^{1} \mathrm{H}$ NMR spectrum of 2 .

The structure of 2 , determined by X-ray diffraction, is shown in Fig. 1. The five-membered carbocycle substituent is essentially planar, with out-of-plane displacements (OOPs) for C1, C2, C7, C8, and C9 that range from $0.003 \AA$ to $0.066 \AA$ (average $\pm 0.042 \AA$ ). In fact, C1, C9, and all seven of the perfluorinated substituent's $\mathrm{C}$ atoms are also co-planar (the nine OOPs range from 0.003 to $0.089 \AA$ and average $\pm 0.032 \AA$ ). The long C1-C9 bond distance of 1.611(3) $\AA$ is typical of $\mathrm{C}_{60}$ derivatives with 3-, 4-, 5-, and 6-membered exocyclic rings. ${ }^{21,22}$

The molecule has idealized $C_{\mathrm{s}}$ symmetry, with the essentially planar faux hawk substituent nearly perpendicular (i.e., $84^{\circ}$ ) to a plane tangent to the idealized fullerene surface at the $\mathrm{C} 1-\mathrm{C} 9$ midpoint (the two C2-C1- $\mathrm{C}_{\text {cage }}$ angles only differ by $c a .2^{\circ}$; the same is true for the two $\mathrm{C} 8-\mathrm{C} 9-\mathrm{C}_{\text {cage }}$ angles). This gives the molecule its "faux-hawk-hairstyle" appearance, as shown in Fig. S-1. $\dagger$ In the OLYP DFT-optimized structure of 2, the faux hawk substituent is rigorously planar (except for F1 and F2) and rigorously perpendicular to the $\mathrm{C}_{60}$ surface. See Table $\mathrm{S}-1 \uparrow$ for a comparison of relevant interatomic distances and angles for the $\mathrm{X}$-ray and OLYP DFT-optimized structures of 2 and Fig. S-3† for a side-by-side comparison of the two structures. Note that the faux hawk substituent in 2 is attached to the type of $\mathrm{C}_{60} \mathrm{C}-\mathrm{C}$ bond that is common to two hexagons. Table $\mathrm{S}-1 \uparrow$ also includes the distances and angles for the OLYP DFT-optimized structure of the isomer with the faux hawk substituent attached a $\mathrm{C}_{60} \mathrm{C}-\mathrm{C}$ 
bond that is common to a pentagon and a hexagon, showing that the faux hawk substituent is sterically congruent in both isomers. Nevertheless, the DFT-predicted relative energy of the unobserved alternate isomer is $62 \mathrm{~kJ} \mathrm{~mol}^{-1}$ above the energy of the observed isomer. This difference is, therefore, fullerene based and not faux hawk-substituent based. As indicated above, the faux hawk substituent in the unobserved and observed isomers is attached to a 5,6-pentagon-hexagon and a 6,6hexagon-hexagon $\mathrm{C}_{60}$ edge, respectively. Attachment of substituent atoms to a 5,6-edge of $\mathrm{C}_{60}$ introduces two $\mathrm{C} \cdots \mathrm{C}$ double bonds in pentagons, each of which is predicted to raise the energy of the $\mathrm{C}_{60}$ core by $33.5 \pm 4.2 \mathrm{~kJ} \mathrm{~mol}^{-1} .^{23}$

There are several other examples of $\mathrm{C}_{60}$ derivatives with fivemembered carbocyclic rings (these are formed by $3+2$ cycloadditions of trimethylenemethanes to $\left.\mathrm{C}_{60}\right),{ }^{24,25}$ but 2 is the only structurally-characterized example in which the carbocycle contains a $\mathrm{C} \cdots \mathrm{C}$ double bond and is therefore planar. It is also the only example in which the carbocycle is perfluorinated.

Fluorine-19 NMR spectra of 1 and 2 are shown in Fig. 3 and 4, respectively. Chemical shifts and coupling constants are listed in Table $\mathrm{S}-2 . \dagger$ The $J(\mathrm{FF})$ coupling constants were determined by simulating the experimental spectra using the program MestReNova 8.1.1. The free rotation about the $\mathrm{F}_{2} \mathrm{C}-\mathrm{C}_{\text {ipso }}$ bond in 1 and the presumed time-averaged $C_{\mathrm{s}}$ symmetry of 2 render the $\mathrm{F}$ atoms in the $\mathrm{CF}_{2}$ moiety magnetically equivalent in both compounds. The aromatic moieties in $\mathbf{1}$ and $\mathbf{2}$ exhibited $\mathrm{bb}^{\prime} \mathrm{cc}^{\prime} \mathrm{d}$ and bcde patterns, respectively (the notation here conforms to the $\mathrm{F}$ atom labels in Fig. 3 and 4 ).

The meta coupling constants $J\left(\mathrm{~F}_{\mathrm{b}} \mathrm{F}_{\mathrm{b}^{\prime}}\right), J\left(\mathrm{~F}_{\mathrm{c}} \mathrm{F}_{\mathrm{c}^{\prime}}\right)$, and $J\left(\mathrm{~F}_{\mathrm{bb}^{\prime}} \mathrm{F}_{\mathrm{d}}\right)$ in 1 and $J\left(\mathrm{~F}_{\mathrm{b}} \mathrm{F}_{\mathrm{d}}\right)$ and $J\left(\mathrm{~F}_{\mathrm{c}} \mathrm{F}_{\mathrm{e}}\right)$ in 2 are all 5-6 Hz. The ortho values, $J\left(\mathrm{~F}_{\mathrm{b}} \mathrm{F}_{\mathrm{c}}\right) / J\left(\mathrm{~F}_{\mathrm{b}^{\prime}} \mathrm{F}_{\mathrm{c}^{\prime}}\right)$ and $J\left(\mathrm{~F}_{\mathrm{cc}^{\prime}} \mathrm{F}_{\mathrm{d}}\right)$ in 1 and $J\left(\mathrm{~F}_{\mathrm{b}} \mathrm{F}_{\mathrm{c}}\right), J\left(\mathrm{~F}_{\mathrm{c}} \mathrm{F}_{\mathrm{d}}\right)$, and $J\left(\mathrm{~F}_{\mathrm{d}} \mathrm{F}_{\mathrm{e}}\right)$ in 2 , are, as expected ${ }^{26}$ significantly larger, $18-26 \mathrm{~Hz}$. The para coupling constants, however, are substantially different for the two compounds; $J\left(\mathrm{~F}_{\mathrm{b}} \mathrm{F}_{\mathrm{c}^{\prime}}\right)=J\left(\mathrm{~F}_{\mathrm{b}^{\prime}} \mathrm{F}_{\mathrm{c}}\right)$ is $7 \mathrm{~Hz}$ in $\mathbf{1}$ and $J\left(\mathrm{~F}_{\mathrm{b}} \mathrm{F}_{\mathrm{e}}\right)$ is 23 $\mathrm{Hz}$ in 2 . The $7 \mathrm{~Hz}$ value for $\mathbf{1}$ is the same as the $c a$. $7 \mathrm{~Hz}$ coupling constants for $\mathrm{F}$ atoms para to one another in perfluorophenyl groups. ${ }^{27}$ The $23 \mathrm{~Hz}$ value for 2 can be compared with the 18-26 $\mathrm{Hz}$ range for $\mathrm{F}$ atoms para to one another in tri- and tetrafluorobenzo $[b]$ thiophenes, ${ }^{28}$ the $14-19 \mathrm{~Hz}$ range in polyfluoroindenes, ${ }^{29}$ and the $12-16 \mathrm{~Hz}$ range in tetrafluorobenzo $[b]$ thiazoles, ${ }^{30}$ compounds that, like 2 , have a polyfluorobenzo moiety fused to a coplanar five-membered ring. The origin of

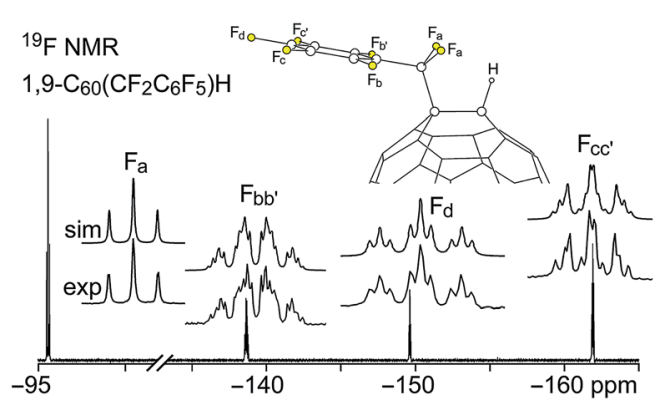

Fig. 3 Experimental and simulated $376.5 \mathrm{MHz}^{19} \mathrm{~F}$ NMR spectra of HPLC-purified 1,9- $\mathrm{C}_{60}\left(\mathrm{CF}_{2} \mathrm{C}_{6} \mathrm{~F}_{5}\right) \mathrm{H}$ (1) in $\mathrm{CDCl}_{3}$. Chemical shifts and coupling constants are listed in Table S-2.†

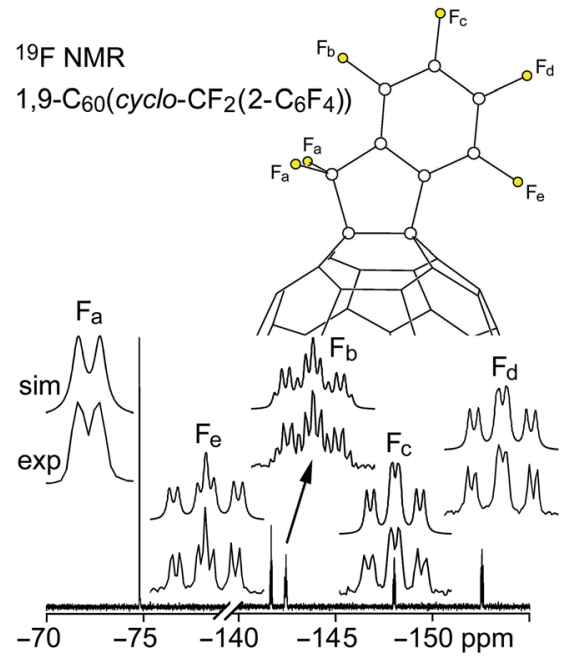

Fig. 4 Experimental and simulated $376.5 \mathrm{MHz}{ }^{19} \mathrm{~F}$ NMR spectra of HPLC-purified $1,9-\mathrm{C}_{60}\left(\right.$ cyclo $\left.-\mathrm{CF}_{2}\left(2-\mathrm{C}_{6} \mathrm{~F}_{4}\right)\right)$ (2) in $\mathrm{CDCl}_{3}$. Chemical shifts and coupling constants are listed in Table S-2.†

the difference in magnitude for para $J(\mathrm{FF})$ values for polyfluorophenyl vs. polyfluorobenzo compounds is not well understood.

On the other hand, the substantial difference in ${ }^{4} J\left(\mathrm{~F}_{\mathrm{a}} \mathrm{F}_{\mathrm{bb}^{\prime}}\right)$ in 1 and ${ }^{4} J\left(\mathrm{~F}_{\mathrm{a}} \mathrm{F}_{\mathrm{b}}\right)$ in $2,30 \mathrm{~Hz}$ and $5.5 \mathrm{~Hz}$, respectively, has a compelling explanation (the ${ }^{4} J\left(\mathrm{~F}_{\mathrm{a}} \mathrm{F}_{\mathrm{bb}^{\prime}}\right)$ value for $\mathrm{C}_{6} \mathrm{~F}_{5} \mathrm{CF}_{2} \mathrm{I}$ is also $30 \mathrm{~Hz})$. In both cases the $\mathrm{F}$ atoms are separated by a $\mathrm{C}\left(\mathrm{sp}^{2}\right)-$ $\mathrm{C}\left(\mathrm{sp}^{3}\right)$ single bond as well as a $\mathrm{C}\left(\mathrm{sp}^{2}\right)-\mathrm{C}\left(\mathrm{sp}^{2}\right)$ bond, and the ${ }^{4} J(\mathrm{FF})$ values are almost certainly dominated by Fermi-contact through-space interactions, ${ }^{31-40}$ which are strongly dependent on the $\mathrm{F} \cdots \mathrm{F}$ distance, the $\mathrm{F}-\mathrm{C} \cdots \mathrm{C}(\mathrm{F})$ angle, and the $\mathrm{F}-\mathrm{C} \cdots \mathrm{C}-\mathrm{F}$ torsion angle. The two $\mathrm{F}_{\mathrm{a}} \cdots \mathrm{F}_{\mathrm{b}}$ distances in the X-ray structure of 2 (these are F1 $\cdots \mathrm{F} 6$ and F2 $\cdots \mathrm{F} 6$ in Fig. 1) are 2.998(6) and 3.151(6) Å, respectively, near the limit of $c a$. 3.2 A for observable Fermi-contact through-space coupling between proximal $\mathrm{F}$ atoms (the corresponding distances in the $C_{\mathrm{s}}$-symmetric DFToptimized structure of 2 are both $3.088 \AA$ ).${ }^{31-40}$ In contrast, the short $\mathrm{F}_{\mathrm{a}} \cdots \mathrm{F}_{\mathrm{b}}$ distances in the $C_{\mathrm{s}}$-symmetric lowest-energy DFToptimized structure of 1 are both $2.587 \AA$, a distance which is comparable to the $2.60-2.65 \AA \mathrm{F} \cdots \mathrm{F}$ distances in compounds previously shown to exhibit ${ }^{4} J(\mathrm{FF})$ values of $19,25,27$, or $48 \mathrm{~Hz}$ depending on the aforementioned angles. ${ }^{39}$

The gas-phase electron affinity (EA) of 2 was determined to be $2.805(10) \mathrm{eV}$ by low-temperature photoelectron spectroscopy (LT-PES) of the $2^{-}$radical anion, as shown in Fig. 5 (cf. 2.683(8) $\mathrm{eV}$ for $\mathrm{C}_{60}$ (ref. 41) and 2.63(1) eV for $\mathrm{PCBM}^{42}$ ). Therefore, 2 is a stronger electron acceptor (in the gas phase) than $\mathrm{C}_{60}$ and PCBM by $0.12(1)$ and $0.18(1) \mathrm{eV}$, respectively. The LT-PES spectrum of $\mathbf{1}^{-}$could not be observed because of the rapid loss of the $\mathrm{H}$ atom to form the closed-shell species $[\mathbf{1}-\mathrm{H}]^{-}$(i.e., $\left.\mathrm{C}_{60}\left(\mathrm{CF}_{2} \mathrm{C}_{6} \mathrm{~F}_{5}\right)^{-}\right)$. Photodetachment of an electron from this anion allowed the $3.75(3) \mathrm{eV} \mathrm{EA}$ of the neutral radical $\mathrm{C}_{60}\left(\mathrm{CF}_{2} \mathrm{C}_{6} \mathrm{~F}_{5}\right)^{\cdot}$ to be determined, but the EA of 1 remains unknown. It is well known that the EA values for fullerene radicals are $c a$. 1-2 eV higher than for closed-shell fullerene derivatives of similar composition. For example, the EA values 


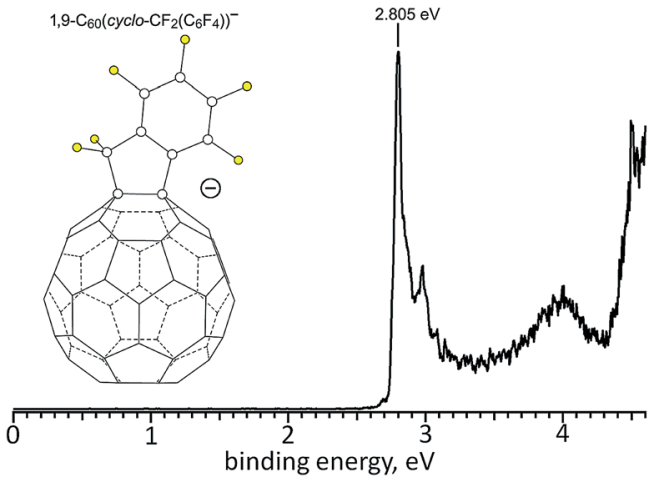

Fig. 5 Low-temperature $266 \mathrm{~nm}$ photoelectron spectrum of the faux hawk fullerene radical ainon $1,9-\mathrm{C}_{60}\left(\text { cyclo }-\mathrm{CF}_{2}\left(2-\mathrm{C}_{6} \mathrm{~F}_{4}\right)\right)^{-}\left(2^{-}\right)$, from which the $2.805(10) \mathrm{eV}$ gas-phase electron affinity of faux hawk fullerene 2 was determined.

for closed-shell $\mathrm{C}_{60} \mathrm{~F}_{46}$, the $\mathrm{C}_{60} \mathrm{~F}_{47} \cdot$ radical, and closed-shell $\mathrm{C}_{60} \mathrm{~F}_{48}$ are $4.06(25),{ }^{43} 5.66(10),{ }^{44}$ and $4.06(30) \mathrm{eV},{ }^{43}$ respectively.

Square-wave and cyclic voltammograms (SWVs and CVs, respectively) of $1,2, \mathrm{C}_{60}$, and $\mathrm{PCBM}$ were recorded under identical conditions in oDCB containing $0.1 \mathrm{M} \mathrm{N}(n-\mathrm{Bu})_{4} \mathrm{BF}_{4}$ and $\mathrm{Fe}(\mathrm{Cp})_{2}$ as an internal standard. In all cases the reduction potentials determined by SWV and by $\mathrm{CV}$ were the same within the $\pm 0.01 \mathrm{~V}$ uncertainty of the individual measurements. The potentials are listed in Table 2 along with $E_{1 / 2}(0 /-)$ values for the related compounds $1,9-\mathrm{C}_{60} \mathrm{H}_{2},{ }^{45,46} 1,9-\mathrm{C}_{60}\left(\mathrm{CH}_{3}\right)_{2},{ }^{47}$ and 1,9$\mathrm{C}_{60}\left(\right.$ cyclo- $\left.\mathrm{C}_{2} \mathrm{~F}_{4}\right) \cdot{ }^{48}$ Our $E_{1 / 2}(0 /-)$ values for $\mathrm{C}_{60}$ and PCBM were first reported in 2013 in the same paper reporting the EA of PCBM. ${ }^{42}$ The CVs for 1, 2, and $\mathrm{C}_{60}$ are shown in Fig. 6. The similarity of $E_{1 / 2}(0 /-)$ values for 2 and $\mathrm{C}_{60}$ is at odds with the $0.12(1) \mathrm{eV}$ difference in their EAs. However, differences in $E_{1 / 2}(0 /-)$ values for fullerene derivatives are generally smaller, and sometimes much smaller, than the corresponding differences in their EAs. ${ }^{\mathbf{4}, 11}$

Removing one of the double bonds of $\mathrm{C}_{60}$ by addition of substituents or a cycloadduct to $\mathrm{C} 1$ and $\mathrm{C} 9$ generally lowers the $E_{1 / 2}(0 /-)$ by $c a$. $0.1 \mathrm{~V}$. For example, $E_{1 / 2}(0 /-)$ values for $1,9-$

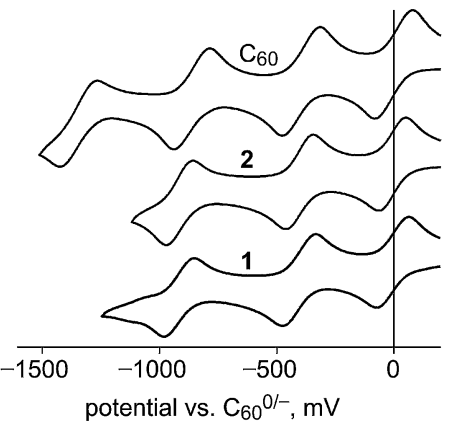

Fig. 6 Cyclic voltammograms of $\mathrm{C}_{60}, 1,9-\mathrm{C}_{60}\left(\mathrm{CF}_{2} \mathrm{C}_{6} \mathrm{~F}_{5}\right) \mathrm{H}$ (1), and 1,9$\mathrm{C}_{60}\left(\right.$ cyclo $\left.-\mathrm{CF}_{2}\left(2-\mathrm{C}_{6} \mathrm{~F}_{4}\right)\right)(2)$ in $1,2-\mathrm{C}_{6} \mathrm{H}_{4} \mathrm{Cl}_{2}$ (oDCB) containing $0.1 \mathrm{M}$ $\mathrm{N}(n-\mathrm{Bu})_{4} \mathrm{BF}_{4}$ and $\mathrm{FeCp}_{2}$ as an internal standard. The $\mathrm{FeCp}_{2}{ }^{+/ 0}$ redox waves are not shown.

$\mathrm{C}_{60}\left(\mathrm{CH}_{2} \mathrm{C}_{6} \mathrm{H}_{5}\right) \mathrm{H},{ }^{20} \mathrm{PCBM}^{42} 1,9-\mathrm{C}_{60}\left(\mathrm{CH}_{3}\right)_{2},{ }^{47}$ and $1,9-\mathrm{C}_{60} \mathrm{H}_{2},{ }^{46}$ are $-0.08,-0.09,-0.12$, and $-0.13 \mathrm{~V}$ vs. $\mathrm{C}_{60}{ }^{0 /-}$, respectively (in each case the comparison with $\mathrm{C}_{60}$ was made under the same conditions of solvent, electrolyte, and temperature). If the cycloadduct is fluorinated and therefore electron withdrawing, as in 2 and 1,9- $\mathrm{C}_{60}\left(\right.$ cyclo- $\left.\mathrm{C}_{2} \mathrm{~F}_{4}\right)$, the $E_{1 / 2}(0 /-)$ values, -0.01 and 0.03 , respectively, have increased by $c a$. $0.1 \mathrm{~V}$ from PCBM-like potentials, resulting in $\mathrm{C}_{60}$-like potentials. The $E_{1 / 2}(0 /-)$ values of 2 and $\mathrm{C}_{60}$ are the same because the offsetting effects of (i) reducing the fullerene $\pi$ system by one double bond and (ii) changing the substituent(s) from hydrocarbyl groups or a hydrocarbyl cycloadduct to a perfluorocarbon cycloadduct cancel each other in this case.

The foregoing analysis is the reason that we were surprised that the three $E_{1 / 2}$ values for $\mathbf{1}$ and $\mathbf{2}$ are so similar. We expected the $E_{1 / 2}(0 /-)$ value for 1 to be $c a$. halfway between 0.03 and $-0.13 \mathrm{~V}$ based on the $E_{1 / 2}(0 /-)$ values in Table 2 , but clearly this is not the case (an ${ }^{19} \mathrm{~F}$ NMR spectrum of $\mathbf{1}$ in the electrolyte solution used for the CV experiments, to which $10 \% \mathrm{C}_{6} \mathrm{D}_{6}$ was added, verified that $\mathbf{1}$ does not react with the electrolyte solution on the timescale of the $\mathrm{CV}$ experiment). We also expected $\mathbf{1}^{-}$to undergo loss of the $\mathrm{H}$ atom to form $[\mathbf{1}-\mathrm{H}]^{-}$, as it did in the

Table 2 Electrochemical reduction potentials ${ }^{a b}$

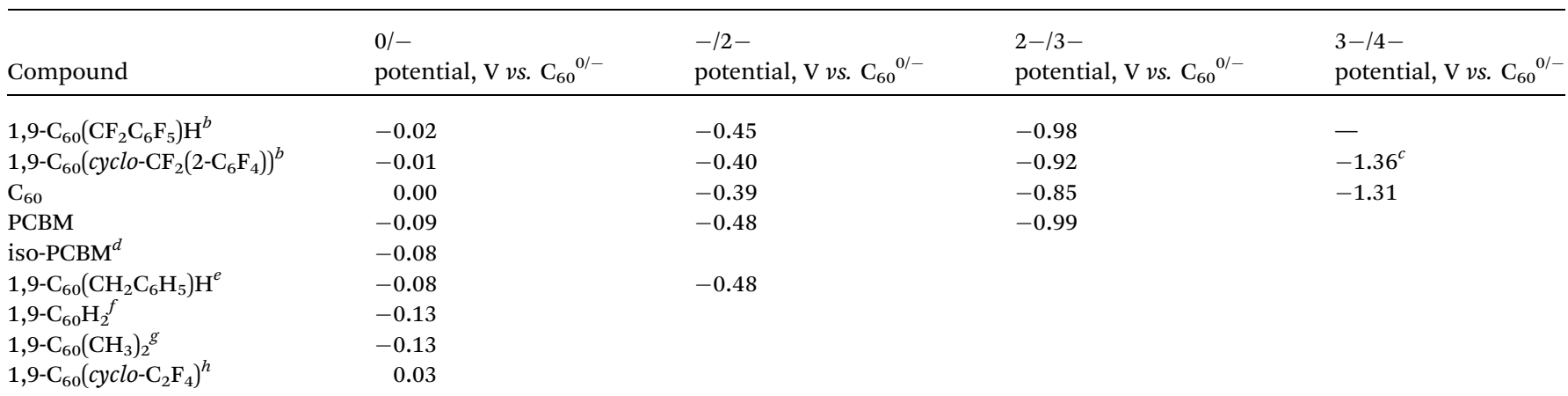

${ }^{a}$ All potentials from cyclic voltammograms unless otherwise indicated. Conditions (unless otherwise noted): purified dinitrogen atmosphere glovebox; $1,2-\mathrm{C}_{6} \mathrm{H}_{4} \mathrm{Cl}_{2}$ (oDCB) solutions at $23(1){ }^{\circ} \mathrm{C} ; 0.1 \mathrm{M} \mathrm{N}(n-\mathrm{Bu})_{4} \mathrm{BF}_{4}$ electrolyte; $\mathrm{Fe}(\mathrm{Cp})_{2}$ internal standard; scan rate $100 \mathrm{mV} \mathrm{s}{ }^{-1}$; Pt working and counter electrodes; $\mathrm{Ag}$ wire quasi-reference electrode. The uncertainty for each measurement is $\pm 0.01 \mathrm{~V} .{ }^{b} 1,9-\mathrm{C}_{60}\left(\mathrm{CF}_{2} \mathrm{C}_{6} \mathrm{~F}_{5}\right) \mathrm{H}=1 ; 1,9-$ $\mathrm{C}_{60}\left(\right.$ cyclo- $\left.\mathrm{CF}_{2}\left(2-\mathrm{C}_{6} \mathrm{~F}_{4}\right)\right)=2 .{ }^{c}$ Potential from square-wave voltammetry. ${ }^{d}$ ref. $105 .{ }^{e}$ At $25{ }^{\circ} \mathrm{C}$ in benzonitrile; ref. $20 .{ }^{f}$ At $-50{ }^{\circ} \mathrm{C}$ in $90 / 10(\mathrm{v} / \mathrm{v})$ toluene/dimethylformamide; ref. $46 .{ }^{g}$ At $25{ }^{\circ} \mathrm{C}$ in benzonitrile; ref. $47 .{ }^{h}$ ref. 48. 
LT-PES experiment discussed above and in the $\mathbf{1}+\mathrm{CoCp}_{2}$ reaction discussed below. Furthermore, hydrofullerenes such as 1,9- $\mathrm{C}_{60} \mathrm{H}_{2},{ }^{45,46}$ 1,9- $\mathrm{C}_{60}\left(\mathrm{CH}_{2} \mathrm{C}_{6} \mathrm{H}_{5}\right) \mathrm{H},{ }^{49}$ and isomers of $\mathrm{C}_{70}\left(\mathrm{CH}_{2} \mathrm{C}_{6} \mathrm{H}_{5}\right) \mathrm{H}^{50}$ are known to undergo observable $\mathrm{H}$-atom loss upon one-electron reduction unless the $\mathrm{CV}$ scan speed is extremely high or the solution is cooled to a low temperature. Nevertheless, our expectations notwithstanding, and in the absence of additional electrochemical experiments, the redox potentials for $\mathbf{1}$ listed in Table 2 are correctly assigned.

\subsection{Understanding the transformation $1 \rightarrow 2+$ "HF"}

According to O3LYP//OLYP DFT calculations, the transformation $\mathbf{1} \rightarrow \mathbf{2}+\mathrm{HF}$ is exothermic by $42 \mathrm{~kJ} \mathrm{~mol}^{-1}$ in the gas phase and $60 \mathrm{~kJ} \mathrm{~mol}^{-1}$ in a PhCN-like dielectric continuum. However, 1 was unchanged after heating an oDCB solution at $160(5){ }^{\circ} \mathrm{C}$ for $2 \mathrm{~h}$. Therefore, this reaction does not occur rapidly by a thermally-activated intramolecular pathway in a non-basic solvent. Nevertheless, the synthesis of $\mathbf{1}$ resulted in the formation of significant amounts of 2 depending on the reaction conditions. To test the idea that 2 can be produced from 1 as an intermediate (although not necessarily as an obligate intermediate), we performed the following series of reactions.

The reagent $\mathrm{SnH}(n-\mathrm{Bu})_{3}$ and byproduct $\mathrm{Sn}_{2}(n-\mathrm{Bu})_{6}$ that are present during the synthesis of 1 and 2 can form $\operatorname{Sn}(n-\mathrm{Bu})_{3}{ }^{\text {* }}$ radicals. In a separate experiment, we heated 1 in oDCB at $160{ }^{\circ} \mathrm{C}$ with added $\mathrm{Sn}_{2}(n-\mathrm{Bu})_{6}$. Unlike the $160{ }^{\circ} \mathrm{C}$ experiment described in the previous paragraph, complete conversion of 1 to 2 occurred within $2 \mathrm{~h}$ in the presence of $\mathrm{Sn}_{2}(n-\mathrm{Bu})_{6}$. Since the reagents $\mathrm{SnH}(n-\mathrm{Bu})_{3}$ and $\mathrm{Sn}_{2}(n-\mathrm{Bu})_{6}$ are not "simple" oneelectron reducing agents, we also studied the reaction of 1 with 1 equiv. of $\mathrm{CoCp}_{2}$ in $\mathrm{PhCN}$ at $23(1){ }^{\circ} \mathrm{C}$. This also caused the conversion of 1 to 2 , as shown by ${ }^{19} \mathrm{~F}$ NMR spectroscopy.

If the one-electron reduced species $\mathbf{1}^{-}$loses an $\mathrm{H}$ atom, as do other one-electron reduced hydrofullerenes (see above), the intermediate would be $\mathrm{CoCp}_{2}{ }^{+} \mathrm{C}_{60}\left(\mathrm{CF}_{2} \mathrm{C}_{6} \mathrm{~F}_{5}\right)^{-}$(i.e., $\mathrm{CoCp}_{2}^{+}[\mathbf{1}-\mathrm{H}]^{-}$), which would react further to form 2 and $\mathrm{CoCp}_{2}{ }^{+} \mathrm{F}^{-}$. A simpler way to generate $[\mathbf{1}-\mathrm{H}]^{-}$is by deprotonation. When 1.0 equiv. of the strong base PS was added to a 90/10 (v/v) PhCN/C ${ }_{6} D_{6}$ solution of 1 at $23(1){ }^{\circ} \mathrm{C}$, the formation of 2 was complete within $5 \mathrm{~min}$, as shown in Fig. 7. At longer times, a new ${ }^{19} \mathrm{~F}$ peak appeared at $\delta$ -139.6. Based on the chemical shift, the magnitude of the coupling constant $(145 \mathrm{~Hz})$, and the abundance of the $I=1 / 2$ species to which the $\mathrm{F}$ atoms are coupled ( $c a .5 \%$ ), the new peak is assigned to an " $\mathrm{SiF}_{n}$ " species, ${ }^{51-56}$ indicating that $\mathrm{HF}$, or species with HF-like reactivity towards glass, such as ion-paired $[\mathrm{H}(\mathrm{PS})]^{+} \mathrm{F}^{-}$ and/or $\mathrm{HF}_{2}{ }^{-}$, were byproducts of the reaction. Rapid exchange between $\mathrm{HF}, \mathrm{F}^{-}$, and $\mathrm{HF}_{2}{ }^{-}$is probably the reason why ${ }^{19} \mathrm{~F}$ peaks due to one or more of these species were not observed during or after the reaction, only an $\mathrm{SiF}_{n}$ species due to reaction of the HF-like species with the walls of the NMR tube. When 1 was treated with excess PS in $\mathrm{CDCl}_{3}$ for $24 \mathrm{~h}$, the reaction mixture contained $24 \% 1,76 \% 2$, and a precipitate (the amounts of 1 and 2 were determined by integrating the ${ }^{19} \mathrm{~F}$ NMR spectrum of the reaction mixture). The precipitate was soluble in $\mathrm{CD}_{3} \mathrm{CN}$ and

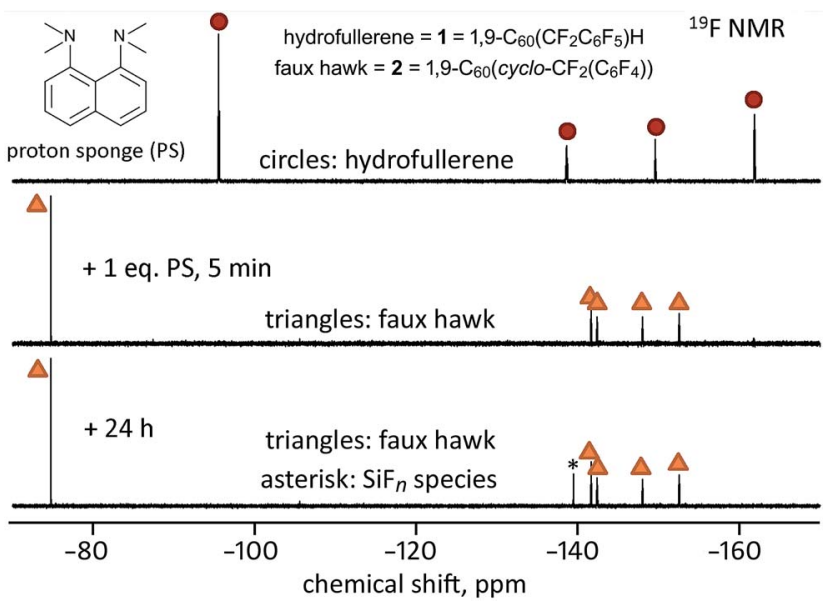

Fig. 7 Fluorine-19 NMR spectra $\left(90 / 10(\mathrm{v} / \mathrm{v}) \mathrm{PhCN} / \mathrm{C}_{6} \mathrm{D}_{6} ; 23(1){ }^{\circ} \mathrm{C}\right)$ of the reaction of hydrofullerene 1 with 1.0 equiv. of PS monitored over time. Note that the formation of faux hawk fullerene 2 is complete after only $5 \mathrm{~min}$ and that the slow growth of an $\mathrm{SiF}_{n}$ species (labeled with an asterisk) over $24 \mathrm{~h}$ indicates that $\mathrm{HF}$ or an HF-like species had been present in solution.

exhibited a $\delta-155.8^{19} \mathrm{~F}$ NMR singlet and a broad $\delta 19.0{ }^{1} \mathrm{H}$ NMR singlet, both of which are commensurate with $\mathrm{H}(\mathrm{PS})^{+} \mathrm{F}^{-} .{ }^{57}$

On the basis of the experiments just described, we propose that the treatment of hydrofullerene 1 with PS resulted in deprotonation to give $\mathrm{H}(\mathrm{PS})^{+}$and $\mathrm{C}_{60}\left(\mathrm{CF}_{2} \mathrm{C}_{6} \mathrm{~F}_{5}\right)^{-}$as first-formed intermediates and that $\mathrm{C}_{60}\left(\mathrm{CF}_{2} \mathrm{C}_{6} \mathrm{~F}_{5}\right)^{-}$formed faux hawk fullerene 2 and " $\mathrm{F}^{--}$" within minutes. At longer times, $[\mathrm{H}(\mathrm{PS})]^{+} \mathrm{F}^{-}$ or an equivalent fluoride-like species present reacted with the glass NMR tube to form the $\mathrm{SiF}_{n}$ species. Even though the putative intermediate $\mathrm{C}_{60}\left(\mathrm{CF}_{2} \mathrm{C}_{6} \mathrm{~F}_{5}\right)^{-}$disappeared too rapidly to observe before an ${ }^{19} \mathrm{~F}$ NMR spectrum could be recorded, its presence can be proposed because simple deprotonation of hydrofullerenes to give anionic fullerene species is well documented (i.e., hydrofullerenes are known to be Brønsted acids: the $\mathrm{p} K_{\mathrm{a}}$ values for $\mathrm{C}_{60}(\mathrm{CN}) \mathrm{H},{ }^{58} \mathrm{C}_{60} \mathrm{H}_{2},{ }^{59}$ and $\mathrm{C}_{60}(t-\mathrm{Bu}) \mathrm{H}^{60}$ were found to be $2.5,4.7$, and 5.7, respectively). Interestingly, when 1 was treated with only 0.25 equiv. of PS in 90/10 (v/v) PhCN/C ${ }_{6} D_{6}$ solution, the complete conversion to 2 also occurred, but only after $48 \mathrm{~h}$, as shown in Fig. 8. This autocatalytic transformation of 1 into 2 presumably results from the first-formed 0.25 equiv. byproduct $\mathrm{F}^{-}$(or $[\mathrm{H}(\mathrm{PS})]^{+} \mathrm{F}^{-}$or $\mathrm{HF}_{2}^{-}$), which formed rapidly, acting as a base and continuing to deprotonate, albeit more slowly, additional molecules of $\mathbf{1}$ until it is completely converted to 2 . In a control experiment to inhibit the proposed catalytic effect of $\mathrm{F}^{-}$as a general base, a few drops of saturated aqueous $\mathrm{Ca}\left(\mathrm{NO}_{3}\right)_{2}$ were added to a similar NMR-scale reaction containing $c a$. 0.3 equiv. of PS (based on 1 ). In this case, the conversion of 1 to 2 was only $30-40 \%$ complete after 48 h, a white gelatinous precipitate formed in the aqueous layer (presumably $\mathrm{CaF}_{2}$ ), and the ${ }^{19} \mathrm{~F}$ NMR peak assigned to the $\mathrm{SiF}_{n}$ species was absent even after $48 \mathrm{~h}$.

The rapid conversion of deprotonated $\mathbf{1}$ (i.e., $[\mathbf{1}-\mathrm{H}]^{-}$) to 2 most likely occurs by an intramolecular $\mathrm{S}_{\mathrm{N}} \mathrm{Ar}$ mechanism whereby the $[\mathbf{1}-\mathrm{H}]^{-}$fullerene carbanion attacks one of the 


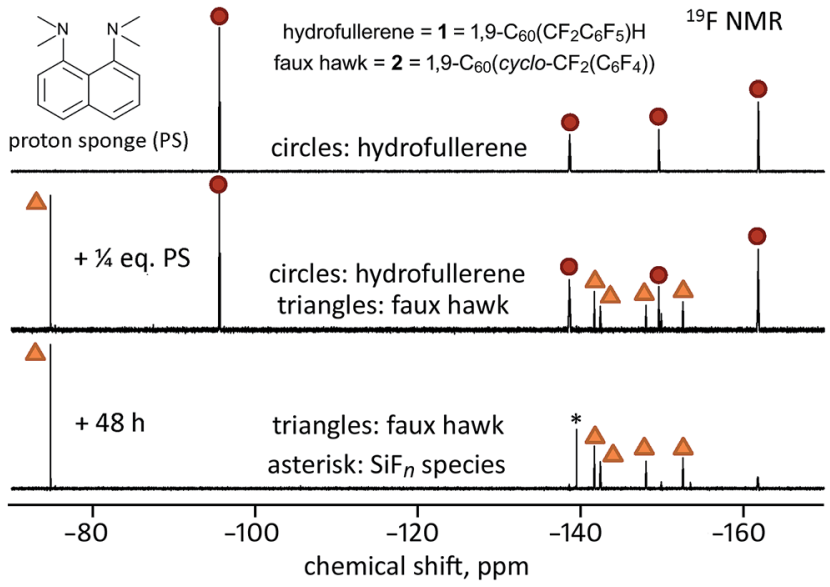

Fig. 8 Fluorine-19 NMR spectra $\left(90 / 10(\mathrm{v} / \mathrm{v}) \mathrm{PhCN} / \mathrm{C}_{6} \mathrm{D}_{6} ; 23(1)^{\circ} \mathrm{C}\right)$ of the reaction of hydrofullerene 1 with 0.25 equiv. of PS monitored over time. Note that the formation of faux hawk fullerene 2 was not complete within minutes (the middle spectrum) or after $48 \mathrm{~h}$, and that the slow growth of an $\mathrm{SiF}_{n}$ species (labeled with an asterisk) over $48 \mathrm{~h}$ indicates that $\mathrm{HF}$ or an $\mathrm{HF}$-like species had been present in solution. Note also that a trace amount of 1 is present in the bottom spectrum.

ortho- $\mathrm{C}-\mathrm{F}$ bonds of the $\mathrm{CF}_{2} \mathrm{C}_{6} \mathrm{~F}_{5}$ substituent. Fullerenes aside, intermolecular $\mathrm{S}_{\mathrm{N}} \mathrm{Ar}$ reactions involving aromatic $\mathrm{C}$-halogen bonds have been extensively studied. ${ }^{61-65}$ In contrast, the scope of intramolecular $\mathrm{S}_{\mathrm{N}} \mathrm{Ar}$ reactions that result in breaking an aromatic $\mathrm{C}-\mathrm{F}$ bond and concomitant loss of $\mathrm{F}^{-}$is limited. ${ }^{66-68}$ In the examples most relevant to this work, Hughes and coworkers showed that perfluorobenzyl ligands on either $\mathrm{Co}^{67}$ or $\mathrm{Rh}^{68}$ can undergo intramolecular $\mathrm{S}_{\mathrm{N}} \mathrm{Ar}$ substitution of an ortho-F atom to form either six- or five-membered chelate rings, respectively. There is general agreement that, all other things being equal, aromatic $\mathrm{C}-\mathrm{F}$ bonds undergo $\mathrm{S}_{\mathrm{N}} \mathrm{Ar}$ substitution much faster than aromatic $\mathrm{C}-\mathrm{Cl}, \mathrm{C}-\mathrm{Br}$, or $\mathrm{C}-\mathrm{I}$ bonds. ${ }^{61-65}$ However, there is still controversy about whether a true Meisenheimer ${ }^{69}$ intermediate is formed (even if it cannot be detected spectroscopically) $)^{\mathbf{7 0 - 7 6}}$ or whether the reaction involves a single Meisenheimer-like transition state. ${ }^{77-80}$

Reactions of $\mathrm{C}_{60} \mathrm{R}^{-}$carbanions with electrophilic substrates EX to form new $\mathrm{C}_{60}(\mathrm{E}) \mathrm{R}$ species and $\mathrm{X}^{-}$are well known, ${ }^{22,81,82}$ but to our knowledge there is no previous example of an $\mathrm{S}_{\mathrm{N}} \mathrm{Ar}$ reaction involving a fullerene cage carbanion (i.e., not including examples such as the negatively-charged $\mathrm{N}$ atom of a deprotonated cyclo-pyrrolidinofullerene undergoing an intermolecular $\mathrm{S}_{\mathrm{N}} \mathrm{Ar}$ reaction with an aryl chloride ${ }^{83}$ ), let alone an intramolecular $S_{N} A r$ reaction of a fullerene cage carbanion attacking an Ar-F bond. Therefore, we decided to test the intramolecular $\mathrm{S}_{\mathrm{N}} \mathrm{Ar}$ hypothesis for the observed transformation $[\mathbf{1}-\mathrm{H}]^{-} \rightarrow \mathbf{2}+$ $\mathrm{F}^{-}$by determining DFT-optimized structures and relative energies for $\mathbf{1}$ and 2 as well as for three different states of $[1-\mathrm{H}]^{-}$. Fig. 9 shows the OLYP DFT-optimized structures and the O3LYP//OLYP relative energies of these five species. Both gas-phase and $\mathrm{PhCN}$-like dielectric continuum relative energies were calculated. Drawings of the upper fragments of the gasphase optimized structures are shown in Fig. 10 and relevant interatomic distances and angles are listed in Table $3 .^{84}$ Larger

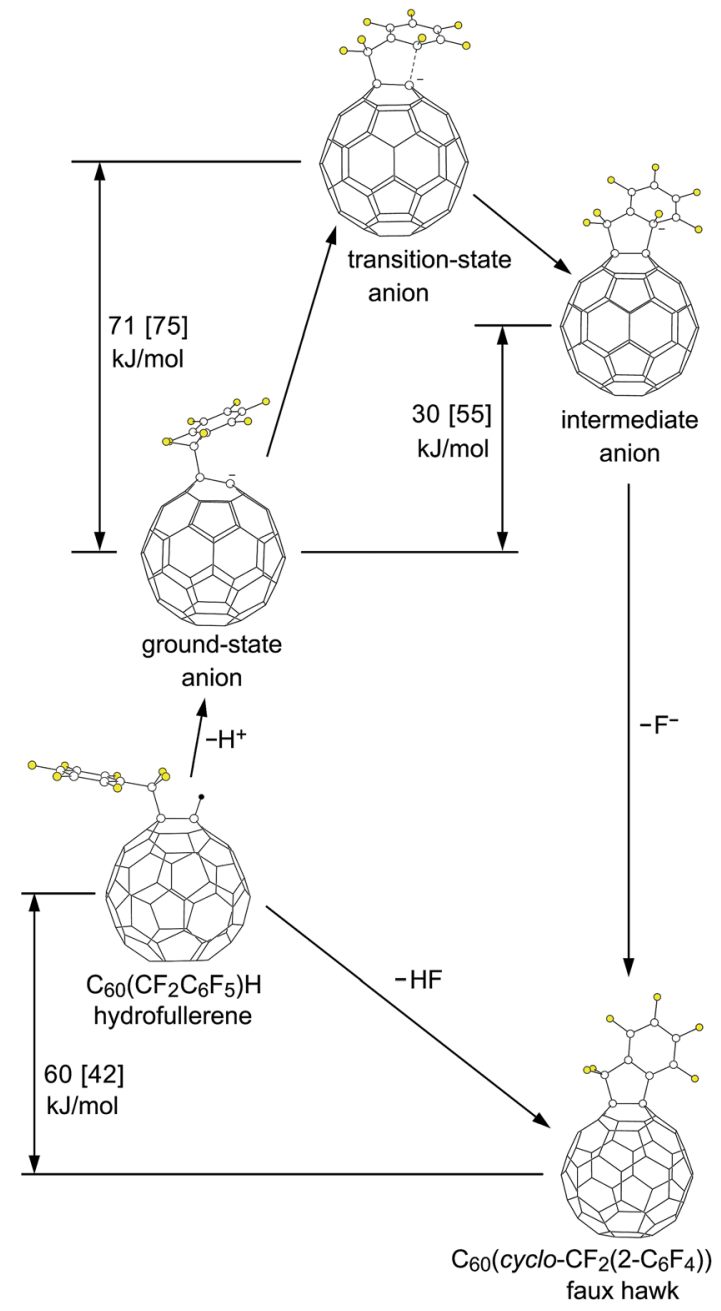

Fig. 9 OLYP DFT-optimized structures and O3LYP//OLYP relative energies of $1,9-\mathrm{C}_{60}\left(\mathrm{CF}_{2} \mathrm{C}_{6} \mathrm{~F}_{5}\right) \mathrm{H}$ (1; hydrofullerene), 1,9- $\mathrm{C}_{60}$ (cyclo$\left.\mathrm{CF}_{2}\left(2-\mathrm{C}_{6} \mathrm{~F}_{4}\right)\right)\left(2\right.$; faux hawk), and the three $[1-\mathrm{H}]^{-}$anions proposed for the $\mathrm{S}_{\mathrm{N}} \mathrm{Ar}$ transformation $\left[1-\mathrm{H}^{-} \rightarrow 2+\mathrm{F}^{-}\right.$(the ground-state, transition-state, and intermediate $\mathrm{C}_{60}\left(\mathrm{CF}_{2} \mathrm{C}_{6} \mathrm{~F}_{5}\right)^{-}$anions). The energy changes shown, which are not to scale on the vertical axis, are for (i) a dielectric continuum equivalent to benzonitrile (no brackets) and (ii) the gas phase (square brackets).

drawings of the optimized species are shown in Fig. S-7 to S-12. $\dagger$ The calculated solvation energies for the ground-state (GS), transition-state (TS), and Meisenheimer-like intermediate-state (IS) structures of the deprotonated $[\mathbf{1}-\mathbf{H}]^{-}$anion are listed in Table $S-3 . \dagger$ This table also lists the gas-phase relative energies using other DFT functionals for the three $[\mathbf{1}-\mathrm{H}]^{-}$states along the proposed $S_{N} A r$ reaction coordinate.

The DFT results show that an $\mathrm{S}_{\mathrm{N}} \mathrm{Ar}$ mechanism is energetically viable for the unimolecular intramolecular annulation reaction $[\mathbf{1}-\mathrm{H}]^{-} \rightarrow \mathbf{2}+\mathrm{F}^{-}$, even without the probable stabilizing effect of hydrogen bonding of either $\mathrm{H}(\mathrm{PS})^{+}$or $\mathrm{HF}$ to the three $[\mathbf{1}-\mathbf{H}]^{-}$structures. The transition state structure of $[\mathbf{1}-\mathrm{H}]^{-}$is only ca. $70 \mathrm{~kJ} \mathrm{~mol}^{-1}$ above the ground-state structure; transition states of $45-130 \mathrm{~kJ} \mathrm{~mol}^{-1}$ have been calculated for non-fullerene $S_{N} A r$ transition states involving nitrogen or sulfur nucleophiles and aromatic $\mathrm{C}-\mathrm{F}$ bonds. $^{\text {74-76 }}$ This is 


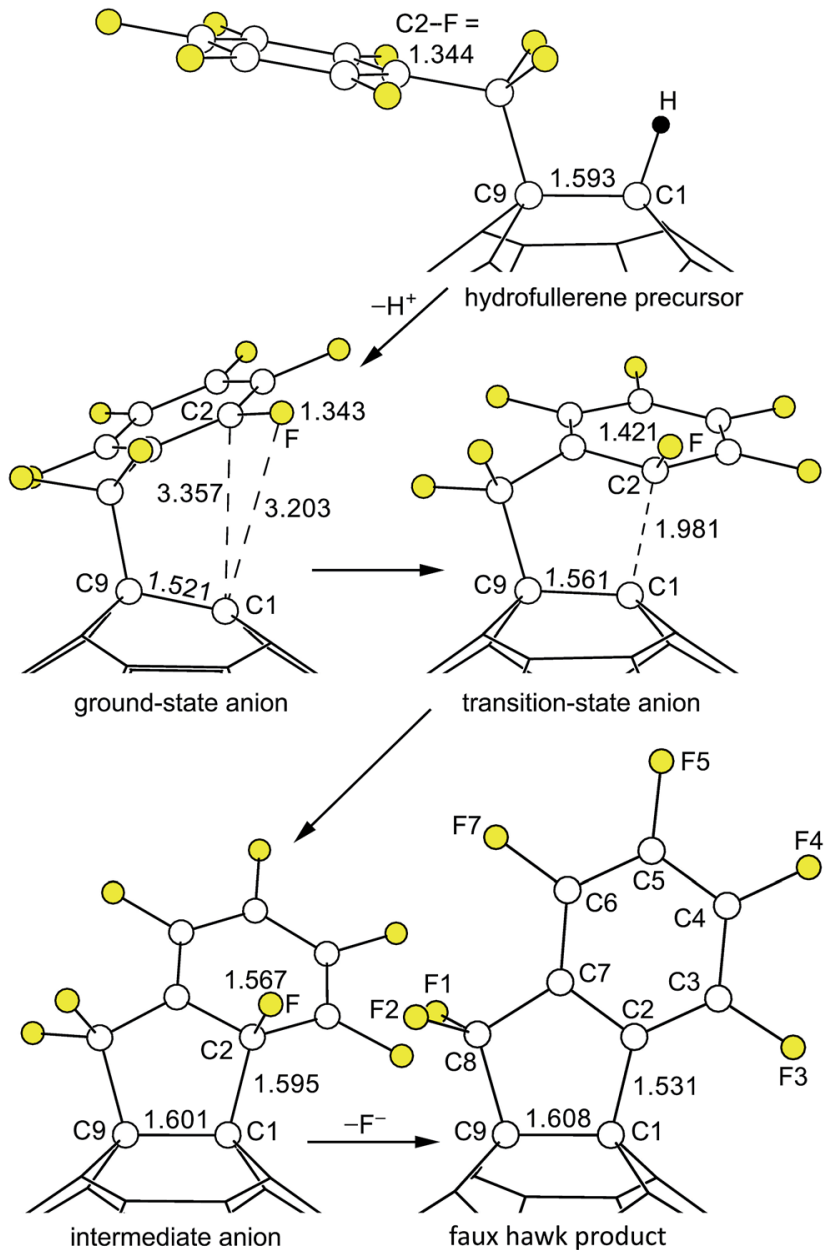

Fig. 10 Parts of the OLYP DFT-optimized structures and O3LYP// OLYP relative energies of $1,9-\mathrm{C}_{60}\left(\mathrm{CF}_{2} \mathrm{C}_{6} \mathrm{~F}_{5}\right) \mathrm{H}$ (1; hydrofullerene), 1,9$\mathrm{C}_{60}\left(\right.$ cyclo $\left.-\mathrm{CF}_{2}\left(2-\mathrm{C}_{6} \mathrm{~F}_{4}\right)\right)\left(2\right.$; faux hawk), and the three $[1-\mathrm{H}]^{-}$anions proposed for the $\mathrm{S}_{\mathrm{N}} \mathrm{Ar}$ transformation $[1-\mathrm{H}]^{-} \rightarrow 2+\mathrm{F}^{-}$(i.e., the ground-state, transition-state, and intermediate $\mathrm{C}_{60}\left(\mathrm{CF}_{2} \mathrm{C}_{6} \mathrm{~F}_{5}\right)^{-}$ anions). Additional distances and angles are listed in Table 3 and are shown in Fig. S-7 through S-12. $\dagger$

consistent with the observed reaction time of only minutes when 1 was mixed with 1 equiv. of PS in 90/10 (v/v) PhCN/ ${ }_{6} D_{6}$ at $23(1){ }^{\circ} \mathrm{C}$. Apparently, there is sufficient conformational flexibility in the $\mathrm{CF}_{2} \mathrm{C}_{6} \mathrm{~F}_{5}$ substituent in $[\mathbf{1}-\mathrm{H}]^{-}$to accommodate the nascent five-membered ring in the transition state.

The structural changes in the C1-C9 moiety of five fullerene species along the proposed $S_{N} A r$ reaction coordinate can be appreciated using Fig. 10 and the results listed in Table 3 . There is a significant change in the degree of pyramidalization $\left(\theta_{\mathrm{p}}\right.$; see Table 3) of $\mathrm{C} 1$ and in the set of three $\mathrm{C} 1-\mathrm{C}$ distances for the first step in the reaction sequence, the deprotonation of $\mathbf{1}$. The former changes from $18.2^{\circ}$ for $\mathbf{1}$ to $9.6^{\circ}$ for GS $[\mathbf{1}-\mathrm{H}]^{-}$and the latter from $\{1.59,1.53,1.53 \AA$ $\}$ for 1 to $\{1.52,1.42,1.43\}$ for GS $[1-\mathrm{H}]^{-}$, signaling a change in hybridization of $\mathrm{C} 1$ from sp ${ }^{3}$ in 1 to a blend of $\mathrm{sp}^{3}$ and $\mathrm{sp}^{2}$ in GS $[\mathbf{1}-\mathrm{H}]^{-}$. The ground-state anion is a carbanion, but the negative charge and the putative "lone pair" are delocalized throughout the $\mathrm{C}_{60}$ cage. Significantly, the $9.6^{\circ} \theta_{\mathrm{p}}$ degree of pyramidalization for C1 in GS $[1-\mathrm{H}]^{-}$is smaller, not larger, than the $11.6^{\circ} \theta_{\mathrm{p}}$ value for the cage $\mathrm{C}$ atoms in $\mathrm{C}_{60}$ (ref. 84) (the delocalization of the negative charge in $\mathrm{C}_{60} \mathrm{R}^{-}$carbanions was previously proposed by Van Lier, Geerlings, and coworkers based on computational results ${ }^{85-87}$ ). As expected, the $\mathrm{C}_{6} \mathrm{~F}_{5}$ rings in $\mathbf{1}$ and GS $[\mathbf{1}-\mathrm{H}]^{-}$are virtually congruent. Even the $\mathrm{C} 8-\mathrm{C} 9$ bond distance is unaffected by the deprotonation.

In the second step, GS $[\mathbf{1}-\mathrm{H}]^{-}$is transformed into TS $[1-\mathrm{H}]^{-}$. Even though the $\mathrm{C} 1 \cdots \mathrm{C} 2$ distance, at $1.981 \AA$, is very long, the C1 $\theta_{\mathrm{p}}$ value increases from $9.6^{\circ}$ to $16.2^{\circ}$, which is $90 \%$ of its original value in 1 . Accordingly, the three $\mathrm{C}_{1}-\mathrm{C}_{\text {cage }}$ distances increase from $\{1.52,1.42,1.43\}$ in GS $[1-\mathrm{H}]^{-}$to $\{1.56$, $1.47,1.48\}$ in TS $[1-\mathrm{H}]^{-}$. At the same time, $\mathrm{C} 2$ is developing $\mathrm{sp}^{3}$ character: the $\mathrm{C} 2-\mathrm{C} 3$ and $\mathrm{C} 2-\mathrm{C} 7$ distances increase from 1.40 and $1.41 \AA$ in GS $[1-\mathrm{H}]^{-}$to 1.43 and $1.44 \AA$ in TS $[1-\mathrm{H}]^{-}$, and the sum of the three angles at $\mathrm{C} 2$ involving $\mathrm{C} 3, \mathrm{C} 7$, and $\mathrm{F}$ is $344^{\circ}$ in TS $[\mathbf{1}-\mathrm{H}]^{-}$whereas this sum is $360^{\circ}$ in GS $[\mathbf{1}-\mathrm{H}]^{-}$. Another way to depict the distortion in the $\mathrm{C}_{6} \mathrm{~F}_{5}$ group in TS $[\mathbf{1}-\mathrm{H}]^{-}$is as follows. The 10 atoms $\mathrm{C} 2-\mathrm{C} 7$ and $\mathrm{F} 3-\mathrm{F} 6$ are coplanar to within $\pm 0.02 \AA$ in both GS $[\mathbf{1}-\mathrm{H}]^{-}$and TS $[\mathbf{1}-\mathrm{H}]^{-}$. However, in $\mathrm{GS}[\mathbf{1}-\mathrm{H}]^{-}$atom $\mathrm{F}$ (i.e., the $\mathrm{F}$ atom bonded to $\mathrm{C} 2$ ) is also in that plane whereas in TS $[\mathbf{1}-\mathrm{H}]^{-}$it is displaced $0.86 \AA$ from that plane. As expected, the C2-F bond in TS $[1-\mathrm{H}]^{-}$, at $1.42 \AA$, is significantly longer than the $1.34 \AA$ distance in both hydrofullerene precursor $\mathbf{1}$ and the GS $[\mathbf{1}-\mathrm{H}]^{-}$anion.

The Meisenheimer-like intermediate, denoted IS $[\mathbf{1}-\mathbf{H}]^{-}$, exhibits further repyramidalization of $\mathrm{C} 1$ and further pyramidalization of $\mathrm{C} 2$. Both of these atoms are essentially tetrahedral in the intermediate, with four single bonds. In fact, the C1 $\theta_{\mathrm{p}}$ value, $19.6^{\circ}$, is only $0.1^{\circ}$ different than the ideal $\theta_{\mathrm{p}}$ tetrahedral angle $\left(19.5^{\circ}\right)$, and the sum of the three angles at $\mathrm{C} 2$ involving $\mathrm{C} 3, \mathrm{C} 7$, and $\mathrm{F}$ is $328.6^{\circ}$, within $0.1^{\circ}$ of the expected sum for a tetrahedral $\mathrm{C}$ atom (i.e., $3 \times 109.5^{\circ}=328.5^{\circ}$ ). Furthermore, the $\mathrm{C} 2-\mathrm{F}$ bond, at $1.567 \AA$, is exceptionally long and is clearly developing a significant amount of $\mathrm{F}^{-}$character. Note that all C-F bond distances measured by X-ray crystallography (as of 1987) are shorter than $1.4 \AA^{.88}$

Finally, in the last step of the reaction sequence shown in Fig. 9 and $10, \mathrm{~F}^{-}$dissociates from the intermediate and the $\mathrm{C}_{6} \mathrm{~F}_{4}$ ring undergoes rearomatization (i.e., the $\mathrm{C} 2-\mathrm{C} 3$ and $\mathrm{C} 2-\mathrm{C} 7$ bond distances shorten from $1.46 \AA$ in IS $[1-\mathrm{H}]^{-}$to $1.40 \AA$ in 2 (therefore all six $\mathrm{C}_{\mathrm{Ar}}-\mathrm{C}_{\mathrm{Ar}}$ distances in 2 are $1.40 \AA$ )).

\subsection{Molecular structure and solid-state packing of 2 and comparison with single-crystal X-ray structures of PCBM}

There are two solvent-free X-ray structures of PCBM: a singlecrystal structure determined using data collected at $100(2) \mathrm{K}$ (ref. 89) and a structure determined by powder X-ray diffraction data collected at 298(2) K. ${ }^{90}$ The molecular structures of 2 and the $100 \mathrm{~K}$ single-crystal structure PCBM $^{89}$ are shown side-by-side in Fig. S-13. $\dagger$ The two substituents have nearly the same number of non-hydrogen atoms, 13 for 2 and 14 for PCBM, but the faux hawk substituent is clearly the more compact. The 1.632(2) $\AA$ C1-C9 bond in PCBM is only marginally longer than the 1.610(5) $\AA$ distance in 2, and fullerene cage atoms C1 and C9 are 
Table 3 DFT-predicted interatomic distances $(\AA)$ and angles (deg) for species along the proposed SNAr reaction coordinate leading from 1 to $2+$ $\mathrm{HF}^{a}$

\begin{tabular}{|c|c|c|c|c|c|}
\hline $\begin{array}{l}\text { Distance or } \\
\text { angle }\end{array}$ & 1 & $\begin{array}{l}\text { Ground-state }[\mathbf{1}-\mathrm{H}]^{-} \\
\text {anion }\end{array}$ & $\begin{array}{l}\text { Transition state }[\mathbf{1}-\mathrm{H}]^{-} \\
\text {anion }\end{array}$ & $\begin{array}{l}\text { Intermediate }[\mathbf{1}-\mathbf{H}]^{-} \\
\text {anion }\end{array}$ & $2^{b}$ \\
\hline $\mathrm{C} 1-\mathrm{C} 2$ & - & 3.357 & 1.981 & 1.595 & 1.531 \\
\hline Other $\mathrm{C} 1-\mathrm{C}_{\text {cage }}$ & $1.527,1.527$ & $1.424,1.425$ & $1.474,1.484$ & $1.528,1.533$ & $1.541,1.541$ \\
\hline $\mathrm{C} 2-\mathrm{F}$ & 1.344 & 1.343 & 1.421 & 1.567 & - \\
\hline Other $\mathrm{C}_{\mathrm{Ar}}-\mathrm{F}$ & $1.342 \times 2,1.339,1.344$ & $1.345 \times 2,1.347 \times 2$ & $1.354,1.356,1,358,1.359$ & $1.356,1.357,1.360,1.364$ & $1.340,1.341,1.342,1.348$ \\
\hline Other $\mathrm{C}_{\mathrm{Ar}}-\mathrm{C}_{\mathrm{Ar}}^{c}$ & $1.395 \times 2,1.397,1.406$ & $1.393 \times 2,1.397,1.405$ & $1.380,1.407,1.392,1.396$ & $1.375,1.390,1.392,1.413$ & $1.395,1.396,1.399,1.401$ \\
\hline $\mathrm{C} 1-\mathrm{C} 2-\mathrm{C} 3$ & - & 136.3 & 117.1 & 120.1 & 128.1 \\
\hline $\mathrm{C} 1-\mathrm{C} 2-\mathrm{C} 7$ & - & 67.6 & 98.2 & 106.2 & 112.9 \\
\hline $\mathrm{C} 3-\mathrm{C} 2-\mathrm{C} 7$ & 121.8 & 121.7 & 116.5 & 113.3 & 119.0 \\
\hline $\mathrm{F}-\mathrm{C} 2-\mathrm{C} 1$ & - & 71.9 & 94.9 & 101.0 & - \\
\hline $\mathrm{F}-\mathrm{C} 2-\mathrm{C} 3$ & 116.5 & 116.1 & 111.6 & 105.6 & - \\
\hline
\end{tabular}

${ }^{a}$ OLYP DFT-optimized structures. $1=1,9-\mathrm{C}_{60}\left(\mathrm{CF}_{2} \mathrm{C}_{6} \mathrm{~F}_{5}\right) \mathrm{H} ; 2=1,9-\mathrm{C}_{60}\left(\right.$ cyclo- $\left.-\mathrm{CF}_{2}\left(2-\mathrm{C}_{6} \mathrm{~F}_{4}\right)\right) .{ }^{b}$ A comparison of the DFT-predicted and experimental Xray diffraction distances and angles for 2 is shown in Table S-1. ${ }^{c}$ These four distances are listed in the order C3-C4, C4-C5, C5-C6, and C6-C7. ${ }^{d}$ The $\pi$-orbital axis vector (POAV) for a fullerene $\mathrm{C}$ atom is defined as the vector that makes equal angles to the three $\mathrm{C}_{\text {cage }}$ atoms to which it is attached (see ref. 84). The common angle is denoted $\theta_{\sigma \pi}$ and $\theta_{\mathrm{p}}=\theta_{\sigma \pi}-90^{\circ}$. The angle $\theta_{\mathrm{p}}$ denotes the degree of pyramidalization of a fullerene cage $\mathrm{C}$ atom. For an idealized trigonal-planar $\mathrm{C}\left(\mathrm{sp}^{2}\right)$ atom, $\theta_{\mathrm{p}}=0^{\circ}$; for an idealized tetrahedral $\mathrm{C}\left(\mathrm{sp}^{3}\right)$ atom, $\theta_{\mathrm{p}}=19.5^{\circ}$.

only slightly less pyramidalized in PCBM $\left(\mathrm{POAV} \theta_{\mathrm{p}}=17.1^{\circ} \times 2\right)$ than in $2\left(\theta_{\mathrm{p}}=18.9\right.$ and $\left.19.1^{\circ}\right)$.

The solvent-free solid-state packing of 2 and PCBM $^{89}$ are analyzed in detail and discussed in the ESI, $\dagger$ along with comparisons to PCBM X-ray structures containing solvent molecules and a related structure (see page S-17 and Fig. S-14 through S-18†). The result of this analysis is that there are only seven (7) nearest neighbor fullerene molecules in crystalline solvent-free PCBM, with $\mathrm{C}_{60}$ centroid $\cdots$ centroid $(\odot \cdots \odot)$ distances of 9.95-10.28 $\AA$. The mean distance is $10.17 \AA$. On the other hand, there are ten (10) nearest neighbors in the structure of 2 , with $\odot \cdots \odot$ distances of $9.74-10.34 \AA$. The mean distance is $10.09 \AA$. The result is that the density of crystalline $2,1.885 \mathrm{~g}$ $\mathrm{cm}^{-3}$, is $15.6 \%$ higher than the $1.631 \mathrm{~g} \mathrm{~cm}^{-3}$ density of solventfree PCBM, even though the molar masses of the two compounds, $918.67 \mathrm{~g} \mathrm{~mol}^{-1}$ for 2 and $910.83 \mathrm{~g} \mathrm{~mol}^{-1}$ for PCBM, differ by only $1.1 \%$. The significance of this is that the aggregation behavior of OPV acceptor fullerenes in the solid state, especially the number of electronically coupled nearest neighbors and their three-dimensional arrangement, is widely believed to be among the key factors that determine charge transport properties in the fullerene domains in Type II heterojunction solar cells. ${ }^{89-100}$

\subsection{Microwave conductivity experiments}

The denser packing of 2 relative to PCBM and the nearly-equal $E_{1 / 2}(0 /-)$ values for 2 and $\mathrm{C}_{60}$ suggested that 2 might be an efficacious electron acceptor in OPV bulk heterojunction thin films. To test this hypothesis, we probed the charge generation and decay dynamics of 2 when blended with regioregular poly-3hexylthiophene (rr-P3HT) using time-resolved microwave conductivity (TRMC). ${ }^{101}$ There are two advantages to measuring photoconductance with TRMC: (i) it is a contactless method and is therefore specific to processes occurring in an OPV active-layer film under illumination; and (ii) the ns- $\mu$ s timescale of TRMC measurements is the same as the timescale of charge-carrier dynamics in an OPV device..$^{95}$ Fig. 11 shows the $\varphi \sum \mu$ TRMC figure of merit for three thinfilm samples ( $\varphi$ is the quantum yield of mobile-charge-carrier generation (i.e., electrons and holes) and $\sum \mu$ is the sum of charge-carrier mobilities at the limit of low excitation intensity). ${ }^{102}$

The $\varphi \sum \mu$ value for a blend of rr-P3HT and 2 is nearly two orders of magnitude higher than for a neat rr-P3HT thin film and is comparable to the $\varphi \sum \mu$ value for an rr-P3HT/PCBM blend, as shown in Fig. 11. The latter observation is indicative of efficient free-charge-carrier generation in the rr-P3HT/2 blend, a combination of a high $\varphi$ value as well as a large $\sum \mu$ contribution due to electron mobility in domains of 2 within the bulk heterojunction thin film, as previously observed for rr-P3HT blends with other high-performance OPV acceptors. ${ }^{95,102,103}$

The decay profiles of the transients for the rr-P3HT/2 and rrP3HT/PCBM blends are nearly identical, as also shown in Fig. 11. The signals are longer lived than for the neat donor polymer, which is normally attributed to high electron mobility in the fullerene phase. ${ }^{102}$ Taken together, the TRMC results indicate that 2 is a promising acceptor for OPV. Its higher electron affinity relative to PCBM suggests that it may be better to blend 2 with "push-pull" low-bandgap donor polymers with HOMO and LUMO energies deeper than P3HT in order to offset open-circuit-voltage losses, ${ }^{\mathbf{1 0 4}}$ and the perfluorinated nature of 

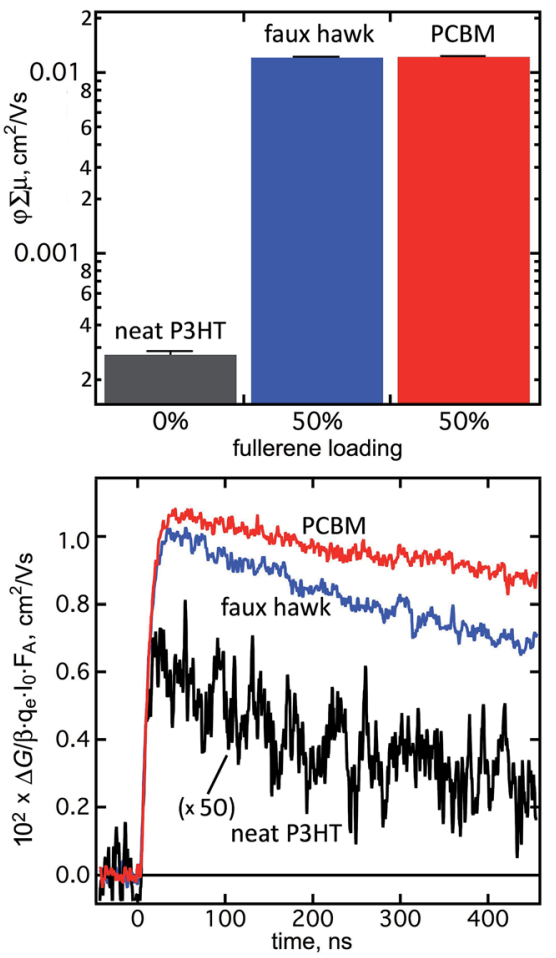

Fig. 11 (Top) Peak $\varphi \sum \mu$ values for thin films of neat P3HT and 50/50 (wt/wt) blends of P3HT and either faux hawk fullerene 1,9- $\mathrm{C}_{60}$ (cyclo$\left.\mathrm{CF}_{2}\left(2-\mathrm{C}_{6} \mathrm{~F}_{4}\right)\right)(2)$ or PCBM. The uncertainty for each measurement is shown on each bar. (Bottom) Transient profile decay curves over 450 ns at incident $500 \mathrm{~nm}$ photon fluxes of ca. $1 \times 10^{13} \mathrm{~cm}^{-2}$ for neat P3HT and ca. $2 \times 10^{11} \mathrm{~cm}^{-2}$ for the blends ( $\Delta G$ is the change in photoconductance, $\beta$ is the ratio of the waveguide cross-section dimensions ( 2.2 in the instrument used), $q_{\mathrm{e}}$ is the electron charge, $I_{0}$ is the incident photon flux, and $F_{\mathrm{A}}$ is the fraction of photons absorbed by the sample).

its substituent suggests and it may be better to blend 2 with fluorinated donor polymers. These experiments are currently underway and will be reported in a future publication.

\subsection{Thermal stability of $1,9-\mathrm{C}_{60}\left(\right.$ cyclo- $\left.\mathrm{CF}_{2}\left(2-\mathrm{C}_{6} \mathrm{~F}_{4}\right)\right)(2)$}

The final comparison we wish to report is the thermal stability of 2 vs. PCBM. It was recently shown that PCBM undergoes substantial decomposition in only 20 min at $340{ }^{\circ} \mathrm{C} .{ }^{105} \mathrm{An}$ HPLC trace of $340{ }^{\circ} \mathrm{C}$-treated PCBM, taken from a figure in ref. 105, is shown in Fig. 12. Part of the $340^{\circ} \mathrm{C}$-treated PCBM sample was a charred residue that did not dissolve in toluene. Of the portion of the sample that did dissolve, only $c a$. $22 \%$ was intact PCBM. The most abundant decomposition product was identified as a new five-membered ring cycloadduct isomer of PCBM that was named iso-PCBM and that is virtually a hydrocarbyl equivalent of 2 (see Fig. S-19† for the structure of iso-PCBM; see also Table 2). ${ }^{105}$

In contrast, the HPLC trace of $340{ }^{\circ} \mathrm{C}$-treated 2 , also shown in Fig. 12, shows no evidence of decomposition unless the traces are vertically expanded 100 times. In the expanded trace, the unambiguous presence of one yet-unidentified new species with an abundance of $c a$. $0.6 \mathrm{~mol} \%$ based on HPLC relative intensities can be seen. In addition, no new peaks were observed in

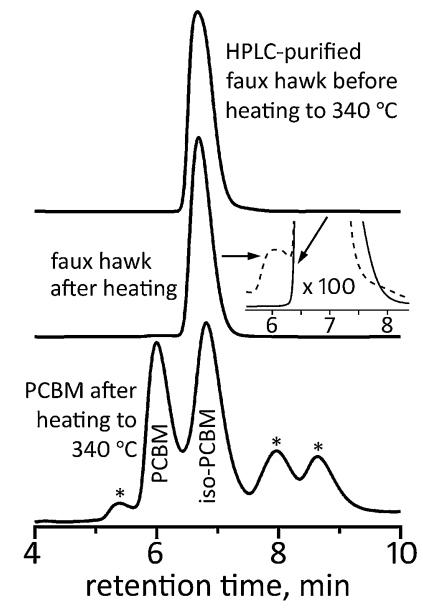

Fig. 12 HPLC traces of faux hawk fullerene 1,9- $\mathrm{C}_{60}\left(\right.$ cyclo $-\mathrm{CF}_{2}(2-$ $\left.\mathrm{C}_{6} \mathrm{~F}_{4}\right)$ ) (2) before and after heating to $340{ }^{\circ} \mathrm{C}$ for 20 min and HPLC trace of PCBM after heating to $340{ }^{\circ} \mathrm{C}$ for $20 \mathrm{~min}$. The PCBM HPLC data were reported in ref. 105. The inset for the middle HPLC trace has been expanded 100 times on the vertical axis (the after-heating trace in the inset is the dashed line). The asterisks in the PCBM after-heating trace are unidentified thermal decomposition products. For all three HPLC traces, a COSMOSIL Buckyprep column was used with a toluene

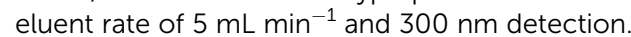

the ${ }^{19} \mathrm{~F}$ NMR spectrum of $340{ }^{\circ} \mathrm{C}$-treated 2. Based on the signal/ noise ratio of that spectrum, the upper limit of any fluorinecontaining compound other than 2 is $c a$. 0.5 mol\%. Significantly, there was no insoluble residue after 2 was heated at $340{ }^{\circ} \mathrm{C}$.

These results are important because post-fabrication thermal annealing of fullerene-containing OPV devices can, in some cases, improve device efficiency and therefore have become common practice in OPV research ${ }^{106,107}$ and because thin films of PCBM or similar fullerene derivatives used for photophysical or electronic property investigations were prepared by high-temperature vacuum sublimation ${ }^{108-110}$ (see also additional references cited in ref. 105). It is possible that the thin films and other materials/devices studied in the papers just cited contained iso-PCBM as well as PCBM and possibly other PCBM thermal decomposition products. How well faux hawk fullerene 2 performs not only in OPV but in other organic electronic applications, especially those that involve thermal annealing and/or thermal evaporation at temperatures up to and including $340{ }^{\circ} \mathrm{C}$, remains to be seen.

\section{Experimental section}

\subsection{General methods, reagents, and solvents}

An inert-atmosphere glovebox and/or standard benchtop inertatmosphere techniques ${ }^{\mathbf{1 1 1}}$ (dioxygen and water vapor levels $\leq 1$ $\mathrm{ppm}$ ) were used to perform reactions and, in general, to prepare samples for spectroscopic, electrochemical, and microwave conductivity analysis. Following filtration through silica gel, reaction mixtures were exposed to air, in most cases with minimal exposure to light. HPLC purifications were also performed in the presence of air. 
The following reagents and solvents were obtained from the indicated sources and were used as received or were purified/ treated/stored as indicated: $\mathrm{C}_{60}$ (MTR Ltd., 99.5+\%); phenyl- $\mathrm{C}_{61^{-}}$ butyric acid methyl ester (PCBM, Nano-C, 99+\%); regioregular (rr) poly-3-hexylthiophene (rr-P3HT, Sigma-Aldrich, 90+\% rr); heptafluorobenzyl iodide $\left(\mathrm{C}_{6} \mathrm{~F}_{5} \mathrm{CF}_{2} \mathrm{I}\right.$, SynQuest, $\left.90 \%\right)$; tri- $n$ butyltin hydride $\left(\mathrm{SnH}(n-\mathrm{Bu})_{3}\right.$, Strem Chemicals, 95+\%), hexabutylditin(Sn-Sn) $\left(\mathrm{Sn}_{2}(n-\mathrm{Bu})_{6}\right.$, Alfa Aesar, 98\%); 1,2-dichlorobenzene (oDCB, Acros Organics, 99\%, dried over and distilled from $\mathrm{CaH}_{2}$ ); dichloromethane (DCM, Fisher Scientific, ACS grade); benzonitrile (PhCN, Aldrich, 99+\%, dried over $3 \AA$ molecular sieves); chloroform-d $\left(\mathrm{CDCl}_{3}, \mathrm{Cambridge}\right.$ Isotope Labs, 99.8\%); benzene- $\mathrm{d}_{6}\left(\mathrm{C}_{6} \mathrm{D}_{6}\right.$, Cambridge Isotope Labs, dried over $3 \AA$ molecular sieves), hexafluorobenzene (Oakwood Products); 1,4-bis(trifluoromethyl)benzene $\left(\mathrm{C}_{8} \mathrm{H}_{4} \mathrm{~F}_{6}\right.$, Central Glass Co., 99\%); ferrocene (FeCp ${ }_{2}$, Acros Organics, 98\%); cobaltocene $\left(\mathrm{CoCp}_{2}\right.$, Strem Chemical, purified by sublimation and stored in the glovebox); silica gel (Sigma-Aldrich, 70-230 mesh, $60 \AA$ ); 1,8-bis(dimethylamino)naphthalene (Proton Sponge (PS), $\mathrm{C}_{14} \mathrm{H}_{18} \mathrm{~N}_{2}$, Sigma-Aldrich, purified by sublimation and stored in the glovebox); toluene (Fisher Scientific, ACS grade); heptane (Mallinckrodt, ACS grade); acetonitrile (Mallinckrodt Chemicals, ACS grade); and tetra- $n$-butylammonium tetrafluoroborate $\left(\mathrm{N}(n-\mathrm{Bu})_{4} \mathrm{BF}_{4}, \mathrm{TBABF}_{4}\right.$, Fluka, puriss grade, dried under vacuum at $70{ }^{\circ} \mathrm{C}$ for $24 \mathrm{~h}$ and stored in the glovebox).

\subsection{Synthesis of compounds}

1,9- $\mathbf{C}_{60}\left(\mathbf{C F}_{2} \mathbf{C}_{\mathbf{6}} \mathbf{F}_{5}\right) \mathbf{H}$. The compounds $\mathrm{C}_{60}(120 \mathrm{mg}, 0.167$ $\mathrm{mmol}), \mathrm{C}_{6} \mathrm{~F}_{5} \mathrm{CF}_{2} \mathrm{I}(0.263 \mathrm{~mL}, 1.67 \mathrm{mmol})$, and $\operatorname{SnH}(n-\mathrm{Bu})_{3}(0.225$ $\mathrm{mL}, 0.835 \mathrm{mmol}$ ) were dissolved in oDCB, heated at $160(5){ }^{\circ} \mathrm{C}$ for $2 \mathrm{~h}$, and cooled to $23(1){ }^{\circ} \mathrm{C}$. All volatiles, including the byproduct $\mathrm{I}_{2}$, were removed from the purple reaction mixture under vacuum. The solid residue was dissolved in toluene, added to a preparative-scale COSMOSIL Buckyprep HPLC column by injection (see below), and eluted with $80 / 20(\mathrm{v} / \mathrm{v})$ toluene/heptane at $16 \mathrm{~mL} \mathrm{m^{-1 }}$ (the HPLC trace is shown in Fig. 2e). The fraction that eluted from 8.0 to $8.3 \mathrm{~min}$ was collected and evaporated to dryness under vacuum, yielding 55 $\mathrm{mg}$ of 1 (35\% yield based on $\mathrm{C}_{60}$ ). The ${ }^{19} \mathrm{~F}$ NMR spectrum of the isolated product (Fig. 3) demonstrates that compound 1 prepared in this way is at least $97 \mathrm{~mol} \%$ pure.

1,9- $\mathbf{C}_{60}\left(\right.$ cyclo- $\left.\mathbf{C F}_{2}\left(2-\mathbf{C}_{6} \mathbf{F}_{4}\right)\right)$. The fraction of the HPLC purification described above that eluted between 9.9 and 10.6 minutes was collected and evaporated to dryness, yielding 11 mg of 2 ( $7 \%$ yield based on $\mathrm{C}_{60}$ ). The ${ }^{19} \mathrm{~F}$ NMR spectrum of the isolated product (Fig. 4) demonstrates that compound 2 prepared in this way is at least $95 \mathrm{~mol} \%$ pure.

Alternatively, $1(5.0 \mathrm{mg})$ was treated with excess Proton Sponge (PS) in $\mathrm{CH}_{2} \mathrm{Cl}_{2}$ at 23(1) C for $24 \mathrm{~h}$. The brown reaction mixture was filtered through silica gel to remove $[\mathrm{H}(\mathrm{PS})]^{+} \mathrm{F}^{-}$and unreacted PS. The filtrate was evaporated to dryness under vacuum. The solid residue was redissolved in toluene, added to the semi-preparative-scale Buckyprep HPLC column by injection (see below), and eluted with toluene at $5 \mathrm{~mL} \min ^{-1}$ (the HPLC trace is shown in Fig. S-20†). The fraction that eluted from
6.8 to 7.9 min was collected and evaporated to dryness under vacuum, yielding $3.9 \mathrm{mg}$ of 2 (76\% yield based on 1 ).

\subsection{Physicochemical methods}

High-performance liquid chromatography. HPLC separation and analysis was carried out on samples exposed to air using a Shimadzu LC-6AD system with a SPD-20A UV/vis detector, a SPD-M20A diode array detector, and a CBM-20A communication bus module. The columns used were preparative- and semipreparative-scale COSMOSIL Buckyprep columns $(20 \times 250 \mathrm{~mm}$ or $10 \times 250 \mathrm{~mm}$, respectively; Nacalai Tesque) and a COSMOSIL Buckyprep-M semi-preparative-scale column $(10 \times 250 \mathrm{~mm}$, Nacalai Tesque) at a flow rate of $5 \mathrm{~mL} \min ^{-1}$ and observed at $370 \mathrm{~nm}$ unless otherwise indicated.

NMR and UV-vis spectroscopy and mass spectrometry. Fluorine-19 (376 MHz) and ${ }^{1} \mathrm{H}(400 \mathrm{MHz})$ NMR spectra were recorded using a Varian INOVA 400 instrument using a $1 \mathrm{~s}$ relaxation time, $60^{\circ}$ pulse angle, and $90 / 10(\mathrm{v} / \mathrm{v}) \mathrm{PhCN} / \mathrm{C}_{6} \mathrm{D}_{6}$ or $\mathrm{CDCl}_{3}$ as the solvent with a trace amount of $\mathrm{C}_{6} \mathrm{~F}_{6}\left(\delta\left({ }^{19} \mathrm{~F}\right)\right.$ $-164.90)$ added as the internal standard. Samples for spectra of 1 or 2 recorded at $23(1){ }^{\circ} \mathrm{C}$ were prepared without the exclusion of air; samples for spectra recorded at elevated temperatures and/or with added PS, $\mathrm{CoCp}_{2}$, or $\mathrm{Sn}_{2}(n-\mathrm{Bu})_{6}$ were prepared anaerobically. The program MestReNova 8.1.1 was used to simulate the ${ }^{19} \mathrm{~F}$ NMR spectra of $\mathbf{1}$ and 2 . The uncertainties in the fitted $J(\mathrm{FF})$ values are probably $\pm 1 \mathrm{~Hz}$. Mass spectra were recorded using a 2000 Finnigan LCQ-DUO mass-spectrometer with $\mathrm{CH}_{3} \mathrm{CN}$ used as the carrier solvent. UV-vis spectra of samples dissolved in toluene were recorded using a Cary 500 UV-vis-NIR spectrometer.

Electrochemistry. Cyclic and square-wave voltammograms were recorded in an inert-atmosphere glovebox using ca. $2 \mathrm{mM}$ oDCB solutions containing $0.1 \mathrm{M} \mathrm{N}(n-\mathrm{Bu})_{4} \mathrm{BF}_{4}$ as the electrolyte, $\mathrm{FeCp}_{2}$ as the internal standard, and a PAR 263 potentiostat/ galvanostat. The electrochemical cell was equipped with 0.125 $\mathrm{mm}$ diameter platinum working and counter electrodes and a $0.5 \mathrm{~mm}$ diameter silver wire quasi-reference electrode. The scan rate was $100 \mathrm{mV} \mathrm{s}^{-1}$.

Electron affinity measurement by low-temperature photoelectron spectroscopy (LT-PES). The spectroscopy and procedures used were described previously. ${ }^{\mathbf{4 4 1}}$ Anions $2^{-}$were generated by electrospraying a $0.1 \mathrm{mM}$ solution of 2 dissolved in toluene/acetonitrile to which a dilute acetonitrile solution of TDAE had been added dropwise until a color change from light brown to brown was observed. The anions were guided by quadrupole ion guides into a cryogenic ion trap, then transferred into the time-of-flight mass spectrometer. Mass-selected anions $2^{-}$were intersected by a Nd:YAG laser (266 nm; $4.661 \mathrm{eV}$ ) in the photodetachment zone of the magnetic-bottle photoelectron analyzer. Photoelectrons were collected at nearly $100 \%$ efficiency, and the energy resolution $(\Delta E / E)$ obtained was $c a$. $2 \%$. The gas-phase electron affinity (EA) of 2 was determined from the $0-0$ transition in the 12 K LT-PES spectrum of the $2^{-}$ radical anion.

Time-resolved microwave conductivity (TRMC). Samples for TRMC were 200-250 nm thick 1/1 (w/w) blended films of 
rr-P3HT and either PCBM or 2 prepared by spin coating $30 \mathrm{mg}$ $\mathrm{mL}^{-1}$ oDCB solutions onto $1 \times 2 \mathrm{~cm}$ quartz substrates in an inert-atmosphere glovebox. Neat P3HT films with similar thicknesses were prepared by spin coating $20 \mathrm{mg} \mathrm{mL}^{-1}$ oDCB solutions in the same way. The samples were placed in the resonance cavity at one end of a $\mathrm{ca} .9 \mathrm{GHz} \mathrm{X}$-band microwave waveguide. The films were exposed through the quartz substrate to $5 \mathrm{~ns}$ pulses of $500 \mathrm{~nm}$ photons using a Continuum Panther optical parametric oscillator pumped by the $355 \mathrm{~nm}$ harmonic of a Continuum Powerlite Q-switched Nd:YAG laser. The transient change in photoconductance $(\Delta G(t))$ was measured by monitoring changes in the microwave power in the cavity $(\Delta P(t))$ due to absorption of microwave photons by photogenerated electrons and holes in the thin film according to the equation:

$$
\Delta G(t)=-\left(K(\Delta P(t) / P)^{-1}\right.
$$

where $K$ is a experimentally-determined calibration factor that depends on the microwave cavity resonance characteristics and the dielectric properties of the sample. ${ }^{\mathbf{1 0 1}}$ The peak photoconductance, $\Delta G_{\text {peak }}$, is used to determine the yield of free carriers (i.e., electron and holes), $\varphi$, times the sum of the free carrier mobilities, $\sum \mu$, according to the equation:

$$
\Delta G_{\text {peak }}=\beta q_{\mathrm{e}} I_{0} F_{\mathrm{A}} \varphi \sum \mu
$$

where $\beta$ is the ratio of the dimensions of the cross-section of the waveguide (2.2 in our instrumentation), $q_{\mathrm{e}}$ is the charge on an electron, $I_{0}$ is the incident photon flux, and $F_{\mathrm{A}}$ is the fraction of laser pump photons absorbed by the sample.

X-ray structure of $1,9-\mathrm{C}_{60}\left(\right.$ cyclo- $\left.\mathrm{CF}_{2}\left(2-\mathrm{C}_{6} \mathrm{~F}_{4}\right)\right)$. Crystals of 2 were grown by slow evaporation of a carbon disulfide solution. Data were collected on the Advanced Photon Source synchrotron instrument on beamline 15ID-B at Argonne National Laboratory, using a wavelength of $0.41328 \AA$, a diamond 111 monochromator, and a Bruker D8 goniometer. Unit cell parameters were obtained from a least-squares fit to the angular coordinates of all reflections. Intensities were integrated from a series of frames from $\omega$ and $\phi$ rotation scans. Absorption and other corrections were applied using TWINABS. ${ }^{112}$ The structure was solved as a non-merohedral twin using direct methods and refined on $F^{2}$ against one major and two minor twin components. Standard Bruker control and integration software (APEX II) was employed, ${ }^{\mathbf{1 1 3 , 1 1 4}}$ and Bruker SHELXTL software was used with Olex 2 for the structure solution, refinement, and molecular graphics. ${ }^{\mathbf{1 1 5 , 1 1 6}}$ For $\mathrm{C}_{67} \mathrm{~F}_{6}: M=918.67$, orthorhombic, $a=$ 9.9998(6), $b=20.6538(12), c=31.3512(18) \AA, V=6475.1(7) \AA^{3}, T$ $=15(2) \mathrm{K}$, space group $P b c a$ (no. 61), $Z=8,9670$ reflections measured, 8340 unique which were used in all calculations. The final $R$ and $\mathrm{w} R$ values are 0.073 (observed reflections) and 0.163 (all reflections), respectively. $\dagger$

Computational methods. Optimization of molecular structures, transition states, and intrinsic reaction coordinate (IRC) calculations were performed in vacuo using the Priroda $\operatorname{code}^{117,118}$ at the OLYP level ${ }^{119,120}$ with the original TZ2P-quality basis set implemented in the code. Point energy calculations at the O3LYP/6-311G** level were performed using Firefly suite. ${ }^{121}$
We used the OLYP and O3LYP functionals because they have been shown to give good results for transition state energies for $\mathrm{S}_{\mathrm{N}} 2$ reactions. ${ }^{\mathbf{1 2 2 - 1 2 4}}$ Solvation energies in benzonitrile (as a model for the experimental solvent mixture 90/10 (v/v) PhCN/ $\mathrm{C}_{6} \mathrm{D}_{6}$ ) was computed using the C-PCM approach ${ }^{\mathbf{1 2 5}}$ implemented in Firefly.

\section{Acknowledgements}

The authors thank the U.S. National Science Foundation (CHE1012468 and 1362302 to CSU and CHE-0822838 to APS), the Office of Basic Energy Sciences, U.S. Department of Energy (DEAC02-06CH11357 to APS), and the Deutsche Forschungsgemeinschaft (Project PO1602/I-1 to IFW Dresden) for funding this research and the Research Computing Center at Moscow State University for computing time on the SKIF-Chebyshev supercomputer. The low-temperature photoelectron spectroscopy work was supported by the U.S. Department of Energy, Office of Science, Office of Basic Energy Sciences, Division of Chemical Sciences, Geosciences \& Biosciences and was performed at EMSL, a national scientific user facility sponsored by the U.S. Department of Energy's Office of Biological and Environmental Research and located at PNNL. The TRMC experiments are based upon work supported by the Solar Photochemistry Program of the U.S. Department of Energy, Office of Science, Office of Basic Energy Sciences through Grant DE-AC36-0-8GO28308 to NREL. We also thank U. Nitzsche for computational assistance, Dr Brian Newell for determining the unit cell parameters of 2 at $120 \mathrm{~K}$, and the late Prof. Dr Lothar Dunsch for his unfailing friendship, guidance, and generous support.

\section{References}

1 O. V. Boltalina, I. V. Kuvychko, N. B. Shustova and S. H. Strauss, in Handbook of Carbon Materials, Volume 1, Syntheses and Supramolecular Systems, ed. F. Desouza and K. M. Kadish, World Scientific, Singapore, 2011, p. 101.

2 N. A. Romanova, M. A. Fritz, K. Chang, N. B. Tamm, A. A. Goryunkov, L. N. Sidorov, C. Chen, S. Yang, E. Kemnitz and S. I. Troyanov, Chem.-Eur. J., 2013, 17, 11707.

3 A. A. Goryunkov, I. V. Kuvychko, I. N. Ioffe, D. L. Dick, L. N. Sidorov, S. H. Strauss and O. V. Boltalina, J. Fluorine Chem., 2003, 124, 61.

4 I. V. Kuvychko, J. B. Whitaker, B. W. Larson, T. C. Folsom, N. B. Shustova, S. M. Avdoshenko, Y. Chen, H. Wen, X. Wang, L. Dunsch, A. A. Popov, O. V. Boltalina and S. H. Strauss, Chem. Sci., 2012, 3, 1399.

5 N. B. Shustova, A. A. Popov, B. S. Newell, S. M. Miller, O. P. Anderson, K. Seppelt, R. D. Bolskar, O. V. Boltalina and S. H. Strauss, Angew. Chem., Int. Ed., 2007, 46, 4111.

6 I. E. Kareev, I. V. Kuvychko, N. B. Shustova, S. F. Lebedkin, V. P. Bubnov, O. P. Anderson, A. A. Popov, S. H. Strauss and O. V. Boltalina, Angew. Chem., Int. Ed., 2008, 47, 6204.

7 I. E. Kareev, A. A. Popov, I. V. Kuvychko, N. B. Shustova, S. F. Lebedkin, V. P. Bubnov, O. P. Anderson, K. Seppelt, 
S. H. Strauss and O. V. Boltalina, J. Am. Chem. Soc., 2008, 130, 13471.

8 A. A. Popov, N. B. Shustova, O. V. Boltalina, S. H. Strauss and L. Dunsch, ChemPhysChem, 2008, 9, 431.

9 N. B. Shustova, I. V. Kuvychko, O. V. Boltalina and S. H. Strauss, Acta Crystallogr., 2007, E63, 04575.

10 A. A. Popov, I. E. Kareev, N. B. Shustova, S. F. Lebedkin, S. H. Strauss, O. V. Boltalina and L. Dunsch, Chem.-Eur. J., 2008, 14, 107.

11 A. A. Popov, I. E. Kareev, N. B. Shustova, E. B. Stukalin, S. F. Lebedkin, K. Seppelt, S. H. Strauss, O. V. Boltalina and L. Dunsch, J. Am. Chem. Soc., 2007, 129, 11551.

12 D. C. Coffey, B. W. Larson, A. W. Hains, J. B. Whitaker, N. Kopidakis, O. V. Boltalina, S. H. Strauss and G. Rumbles, J. Phys. Chem. C, 2012, 116, 8916.

13 I. V. Kuvychko, B. W. Larson, S. H. Strauss and O. V. Boltalina, in Efficient Preparation of Fluorine Compounds, ed. H. Roesky, Wiley, New York, 2012, p. 19.

14 T. T. Clikeman, I. V. Kuvychko, N. B. Shustova, Y.-S. Chen, A. A. Popov, O. V. Boltalina and S. H. Strauss, Chem.-Eur. J., 2013, 19, 5070.

15 I. V. Kuvychko, N. B. Shustova, S. M. Avdoshenko, A. A. Popov, S. H. Strauss and O. V. Boltalina, Chem.-Eur. J., 2011, 17, 8799.

16 M. Yoshida, D. Suzuki and M. Iyoda, Chem. Lett., 1996, 1097.

17 K. M. Kadish, X. Gao, E. Van Caemelbecke, T. Suenobu and S. Fukuzumi, J. Phys. Chem. A, 2000, 104, 3878.

18 M. Yoshida, A. Morishima, Y. Morinaga and M. Iyoda, Tetrahedron Lett., 1994, 35, 9045.

19 B. Jousselme, G. Sonmez and F. Wudl, J. Mater. Chem., 2006, 16, 3478.

20 W.-W. Yang, Z.-J. Li and X. Gao, J. Org. Chem., 2010, 75, 4086.

21 I. S. Neretin and Y. L. Slovokhotov, Russ. Chem. Rev., 2004, 73, 455.

22 A. Hirsch and M. Brettreich, Fullerenes - Chemistry and Reactions, Wiley-VCH, Weinheim, 2005.

23 D. A. Dixon, N. Matsuzawa, T. Fukunaga and F. N. Tebbe, J. Phys. Chem., 1992, 96, 6107.

24 M. Prato, T. Suzuki, H. Foroudian, Q. Li, K. Khemani, F. Wudl, J. Leonetti, R. D. Little, T. White, B. Rickborn, S. Yamago and E. Nakamura, J. Am. Chem. Soc., 1993, 115, 1594.

25 E. Nakamura and S. Yamago, Acc. Chem. Res., 2002, 35, 867. 26 J. W. Emsley, L. Phillips and V. Wray, Prog. Nucl. Magn. Reson. Spectrosc., 1976, 10, 83.

27 K. Bynum, R. Prip, R. Callahan and R. Rothchild, J. Fluorine Chem., 1998, 90, 39.

28 M. D. Castle, E. F. Mooney and R. G. Plevey, Tetrahedron, 1968, 24, 5457.

29 R. S. Matthews and W. E. Preston, Org. Magn. Reson., 1980, 14, 258.

30 F. E. Herkes, J. Fluorine Chem., 1978, 12, 1.

31 L. Petrakis and C. H. Sederholm, J. Chem. Phys., 1961, 35, 1243.
32 K. Hirao, H. Nakatsuji and H. Kato, J. Am. Chem. Soc., 1972, 95, 31 .

33 F. B. Mallory, J. Am. Chem. Soc., 1973, 95, 7747.

34 J. E. Peralta, R. H. Contreras and J. P. Snyder, Chem. Commun., 2000, 2025.

35 W. D. Arnold, J. Mao, H. Sun and E. Oldfield, J. Am. Chem. Soc., 2000, 122, 12164.

36 T. Tuttle, J. Grafenstein and D. Cremer, Chem. Phys. Lett., 2004, 394, 5.

37 L. Krcsmar, J. Grunenberg, I. Dix, P. G. Jones, K. Ibrom and L. Ernst, Eur. J. Org. Chem., 2005, 5306.

38 I. E. Kareev, I. V. Kuvychko, S. F. Lebedkin, S. M. Miller, O. P. Anderson, K. Seppelt, S. H. Strauss and O. V. Boltalina, J. Am. Chem. Soc., 2005, 127, 8362.

39 I. E. Kareev, G. Santiso-Quinones, I. V. Kuvychko, I. N. Ioffe, I. V. Goldt, S. F. Lebedkin, K. Seppelt, S. H. Strauss and O. V. Boltalina, J. Am. Chem. Soc., 2005, 127, 11497.

40 N. B. Shustova, I. V. Kuvychko, R. D. Bolskar, K. Seppelt, S. H. Strauss, A. A. Popov and O. V. Boltalina, J. Am. Chem. Soc., 2006, 128, 15793.

41 X. B. Wang and L. S. Wang, Rev. Sci. Instrum., 2008, 79, 073108.

42 B. W. Larson, J. B. Whitaker, X.-B. Wang, A. A. Popov, G. Rumbles, N. Kopidakis, S. H. Strauss and O. V. Boltalina, J. Phys. Chem. C, 2013, 117, 14958.

43 R. Hettich, C. M. Jin and R. Compton, Int. J. Mass Spectrom. Ion Processes, 1994, 138, 263.

44 X.-B. Wang, C. Chi, M. Zhou, I. V. Kuvychko, K. Seppelt, A. A. Popov, S. H. Strauss, O. V. Boltalina and L.-S. Wang, J. Phys. Chem. A, 2010, 114, 1756.

45 T. F. Guarr, M. S. Meier, V. K. Vance and M. Clayton, J. Am. Chem. Soc., 1993, 115, 9862.

46 P. Boulas, F. D'Souza, C. C. Henderson, P. A. Cahill, M. T. Jones and K. Kadish, J. Phys. Chem., 1993, 97, 13435.

47 C. Caron, R. Subramanian, F. D'Souza, J. Kim, W. Kutner, M. T. Jones and K. Kadish, J. Am. Chem. Soc., 1993, 115, 8505.

48 I. V. Kuvychko, Ph.D. dissertation, Colorado State Univ., 2012.

49 W.-W. Yang, Z.-J. Li and X. Gao, J. Org. Chem., 2011, 76, 6067.

50 L. Ni, W. Chang, H.-L. Hou, Z.-J. Li and X. Gao, Org. Biomol. Chem., 2011, 9, 6646.

51 S. G. Frankiss, J. Phys. Chem., 1967, 71, 3418.

52 T. Q. Nguyen, F. Qu, X. Huang and A. F. Janzen, Can. J. Chem., 1992, 70, 2089.

53 W. Makulski, J. Mol. Struct., 2013, 1036, 168.

54 K. George, A. L. Hector, W. Levason, G. Reid, G. Sanderson, M. Webster and W. Zhang, Dalton Trans., 2011, 40, 1584.

55 W. Levason, D. Pugh and G. Reid, Inorg. Chem., 2013, 52, 5185.

56 V. O. Gelmboldt, E. V. Ganin, M. M. Botoshansky, V. Y. Anisimov, O. V. Prodan, V. C. Kravtsov and M. S. Fonari, J. Fluorine Chem., 2014, 160, 57.

57 R. D. Chambers, S. R. Korn and G. Sandford, J. Fluorine Chem., 1994, 69, 103. 
58 M. Keshavzarz-K, B. Knight, G. Srdanov and F. Wudl, J. Am. Chem. Soc., 1995, 117, 11371.

59 E. Champeil, C. Crean, C. Larraya, G. Pescitelli, G. Proni and L. Ghosez, Tetrahedron, 2008, 64, 10319.

60 P. J. Fagan, P. J. Krusic, D. H. Evans, S. A. Lerke and E. Johnston, J. Am. Chem. Soc., 1992, 114, 9697.

61 R. A. Bunce, E. J. Lee and M. T. Grant, J. Heterocycl. Chem., 2011, 48, 620.

62 R. A. Bunce, T. Nego, N. Sonobe and L. M. Slaughter, J. Heterocycl. Chem., 2009, 45, 551.

63 N. S. Goulioukina, A. Y. Mitrofanov and I. P. Beletskaya, J. Fluorine Chem., 2012, 136, 26.

64 Y. Xiong, J. Wu, S. Xiao and S. Cao, Chin. J. Chem., 2012, 30, 2747.

65 A. Pažitný, T. Solčán and D. Végh, J. Fluorine Chem., 2009, 130, 267.

66 R. P. Houghton and M. Voyle, J. Organomet. Chem., 1983, 259, 183.

67 R. P. Hughes and D. C. Lindner, Organometallics, 1996, 15, 5678.

68 R. P. Hughes, D. C. Lindner, L. M. Liable-Sands and A. L. Rheingold, Organometallics, 2001, 20, 363.

69 J. Meisenheimer, Justus Liebigs Ann. Chem., 1902, 323, 205. 70 L. Forlani, C. Boga, A. Mazzanti and N. Zanna, Eur. J. Org. Chem., 2012, 1123.

71 R. A. Manderville, J. M. Dust and E. Buncel, J. Phys. Org. Chem., 1996, 9, 515.

72 J. Miller, Aromatic Nucleophilic Substitution, Elsevier, Amsterdam, 1968.

73 L. C. Chan, B. G. Cox, I. C. Jones and S. Tomasi, J. Phys. Org. Chem., 2011, 24, 751.

74 N. Chéron, L. El Kaïm, L. Gramaud and P. Fleurat-Lessard, Chem.-Eur. J., 2011, 17, 14929.

75 A. Nova, R. Mas-Ballesté and A. Lledós, Organometallics, 2012, 31, 1245.

76 S. Park and S. Lee, Bull. Korean Chem. Soc., 2010, 31, 2571.

77 Z. Wu and R. Glaser, J. Am. Chem. Soc., 2004, 126, 10632.

78 A. H. Renfrew, J. A. Taylor, J. M. J. Whitmore and A. Williams, J. Chem. Soc., Perkin Trans. 2, 1993, 1703.

79 M. N. Glukhovtsev, R. D. Bach and S. J. Laiter, J. Org. Chem., 1997, 62, 4036.

80 I. Fernández, G. Frenking and E. Uggerud, J. Org. Chem., 2010, 75, 2971.

81 A. Hirsch, in Fullerenes and Related Structures, ed. A. Hirsch, Springer, Berlin, 1999, p. 1.

82 T. Kitagawa and K. Takeuchi, Bull. Chem. Soc. Jpn., 2001, 74, 785.

83 P. de la Cruz, A. de la Hoz, F. Langa, N. Martín, M. C. Pérez and L. Sánchez, Eur. J. Org. Chem., 1999, 3433.

84 R. C. Haddon, Science, 1993, 261, 1545.

85 K. Choho, G. Van Lier, G. Van De Woude and P. Geerlings, J. Chem. Soc., Perkin Trans. 2, 1996, 1723.

86 G. Van Lier, B. Safi and P. Geerlings, J. Chem. Soc., Perkin Trans. 2, 1998, 349.

87 M. C. Amat, G. Van Lier, M. Solà, M. Duran and P. Geerlings, J. Org. Chem., 2004, 69, 2374.
88 F. H. Allen, O. Kennard, D. G. Watson, L. Brammer, A. G. Orpen and R. Taylor, J. Chem. Soc., Perkin Trans. 2, 1987, S1.

89 G. Paternò, A. J. Warren, J. Spencer, G. Evans, V. García Sakai, J. Blumberger and F. Cacialli, J. Mater. Chem., 2013, 1, 5619.

90 M. Casalegno, S. Zanardi, F. Frigerio, R. Po, C. Carbonera, G. Marra, T. Nicolini, G. Raos and S. V. Meille, Chem. Commun., 2013, 49, 4525.

91 R. C. I. MacKenzie, J. M. Frost and J. Nelson, J. Chem. Phys., 2010, 132, 064904.

92 D. L. Cheung and A. Troisi, J. Phys. Chem. C, 2010, 114, 20479.

93 J. H. Choi, T. Honda, S. Seki and S. Fukuzumi, Chem. Commun., 2011, 47, 11213.

94 H. Oberhofer and J. Blumberger, Phys. Chem. Chem. Phys., 2012, 14, 13846.

95 A. M. Nardes, A. J. Ferguson, J. B. Whitaker, B. W. Larson, R. E. Larsen, K. Maturová, P. A. Graf, O. V. Boltalina, S. H. Strauss and N. Kopidakis, Adv. Funct. Mater., 2012, 22, 4115.

96 F. Gajdos, H. Oberhofer, M. Dupuis and J. Blumberger, J. Phys. Chem. Lett., 2013, 4, 1012.

97 M. T. Rispens, A. Meetsma, R. Rittberger, C. J. Brabec, N. S. Sariciftci and J. C. Hummelen, Chem. Commun., 2003, 2116.

98 N. R. Tummala, S. Mehraeen, Y.-T. Fu, C. Risko and J.-L. Brédas, Adv. Funct. Mater., 2013, 23, 5800.

99 C. J. Tassone, A. L. Ayzner, R. D. Kennedy, M. Halim, M. So, Y. Rubin, S. H. Tolbert and B. J. Schwartz, J. Phys. Chem. C, 2011, 115, 22564.

100 R. D. Kennedy, M. Halim, S. I. Khan, B. J. Schwartz, S. H. Tolbert and Y. Rubin, Chem.-Eur. J., 2012, 18, 7418.

101 T. J. Savenije, A. J. Ferguson, N. Kopidakis and G. Rumbles, J. Phys. Chem. C, 2013, 117, 24085.

102 A. J. Ferguson, N. Kopidakis, S. E. Shaheen and G. Rumbles, J. Phys. Chem. C, 2011, 115, 23134.

103 W. J. Grzegorczyk, T. J. Savenije, T. E. Dykstra, J. Piris, J. M. Schins and L. D. A. Siebbeles, J. Phys. Chem. C, 2010, 114, 5182.

104 P.-L. T. Boudreault, A. Najari and M. Leclerc, Chem. Mater., 2011, 23, 456.

105 B. W. Larson, J. B. Whitaker, A. A. Popov, N. Kopidakis, G. Rumbles, O. V. Boltalina and S. H. Strauss, Chem. Mater., 2014, 26, 2361.

106 F. Padinger, R. S. Rittberger and N. S. Sariciftci, Adv. Funct. Mater., 2003, 13, 85.

107 E. Verploegen, R. Mondal, C. J. Bettinger, S. Sok, M. F. Toney and Z. Bao, Adv. Funct. Mater., 2010, 20, 3519.

108 W.-H. Tseng, J.-Y. Wang, M.-H. Chen, C.-Y. Wang, H. Lo and C.-I. Wu, J. Photonics Energy, 2012, 2, 021009.

109 V. S. Reddy, S. Karak, S. K. Ray and A. Dhar, J. Phys. D: Appl. Phys., 2009, 42, 145103.

110 A. Kumar, G. Li, Z. Hong and Y. Yang, Nanotechnology, 2009, 20, 165202. 
111 D. F. Shriver and M. A. Drezdzon, The Manipulation of AirSensitive Compounds, Wiley-Interscience, New York, 2nd edn, 1986.

112 G. M. Sheldrick, TWINABS: Bruker AXS Scaling for Twinned Crystals (v. 2012/1), Bruker AXS, Madison, WI, 2003.

113 G. M. Sheldrick, Crystallography Program APEX2 (v. 5-0), Bruker AXS, Madison, WI, 2014.

114 G. M. Sheldrick, Acta Crystallogr., 2008, A64, 112.

115 G. M. Sheldrick, Crystallography Software Package SHELXTL (v. 6.14 UNIX), Bruker AXS, Madison, WI, 2001.

116 O. V. Dolomanov, L. J. Bourhis, R. J. Gildea, J. A. K. Howard and H. Puschmann, J. Appl. Crystallogr., 2009, 42, 339.

117 D. N. Laikov, Chem. Phys. Lett., 1997, 281, 151.
118 D. N. Laikov and Y. A. Ustynyuk, Russ. Chem. Bull., 2005, 54, 820.

119 C. Lee, W. Yang and R. G. Parr, Phys. Rev. B: Condens. Matter Mater. Phys., 1988, 37, 785.

120 N. C. Handy and A. J. Cohen, Mol. Phys., 2001, 99, 403.

121 A. A. Granovsky, Firefly (v. 8.0.0), 2013.

122 M. Swart, M. Solà and F. M. Bickelhaupt, J. Comput. Chem., 2007, 28, 1551.

123 A. P. Bento, M. Solà and F. M. Bickelhaupt, J. Chem. Theory Comput., 2008, 4, 929.

124 M. Swart, M. Sola and F. M. Bickelhaupt, J. Chem. Phys., 2009, 131, 094103.

125 M. Cossi, N. Rega, G. Scalmani and V. Barone, J. Comput. Chem., 2003, 24, 669. 